\title{
DESEGREGATION AND BLACK ACHIEVEMENT: A REVIEW OF THE RESEARCH*
}

\author{
Robert L. Crain† and Rita E. Mahard $\ddagger$
}

\section{INTRODUCTION}

The effect of desegregation on the performance of black and white students on achievement tests has received an undeserved emphasis in the desegregation literature. There are over a hundred studies of achievement test performance following desegregation. When this is contrasted with the number of studies on other aspects of desegregation, the emphasis is embarrassing-even more embarrassing when the justification for this research is considered. In part, research on the effects of desegregation on achievement test scores is undertaken in the belief that the major problem facing minorities-especially blacks-in this society is their lack of cognitive ability. This argument has been virtually demolished by recent analyses indicating that only a small proportion of the difference in income between blacks and whites can be related statistically to racial differences in cognitive performance. ${ }^{1}$ Nevertheless, the emphasis on achievement test scores continues.

The performance of blacks on achievement tests is also of concern because for seventy-five years the lower performance of blacks on such tests has been used to support beliefs in their racial inferiority. Furthermore, it is likely that many black as well as white elites still subscribe to the theory that one can measure the economic productivity and, for that matter, the moral worth of human beings in terms of whether they can state correctly the Pythagorean theorem, add two improper fractions, or select the answer on a multiple choice battery that indicates they have properly decoded a paragraph about the nesting habits of bluebirds. Even assuming that achievement test performance is important, it is still questionable whether factors like the rate of

\footnotetext{
* Research was supported by the National Review Panel on School Desegregation Research, through funding provided by the Ford Foundation, the National Institute of Education, and Duke University; and by NIE grant G-78-0150, Ronald Henderson, project officer. The assistance of Karen Mokrzycki, Lida Nash, Barbara Neff, and Reginald Van Driest, research librarians of the Rand Corporation, is gratefully acknowledged. We wish to thank Christine Rossell for her thoughtful commentary.

† Senior Social Scientist, The Rand Corporation; presently, Academic Visitor, The London School of Economics.

$¥$ Assistant Social Scientist, The Rand Corporation.

1. See C. Jencks, M. Smith, H. Acland, M. Bane, D. Cohen, H. Gintis, B. Heyns, \& S. Michelson, INEQUALITY 81 (1972).
} 
change in cognitive performance between the ages of seven and nine will have any great bearing on a student's ability to perform cognitive tasks as an adult.

Although there are good reasons not to overemphasize the importance of achievement test performance, a review of the research literature is still worthwhile. All else being equal, it is probably better to obtain a high score on a test than a low score. The fact that students at a particular school score well may indicate that the school has done a good job of making students want to learn and to do well on tests, which in the long run may be as important as what they actually learn.

One clear answer has already emerged from the research literature on desegregation: virtually every writer on the subject has agreed that the test performance of white students is unaffected by school desegregation. ${ }^{2}$ It is safe to assume this issue is settled, at least until some dramatic new research is done; accordingly, the effect of desegregation on the achievement test scores of whites is ignored in this article.

Researchers and writers find it harder, however, to agree on the effect of desegregation on black student achievement, and many argue the merits of desegregation policy on the basis of differing interpretations of the research in this area. The future of desegregation policy will not and should not be determined by test scores, nor will the Supreme Court reverse the Brown ${ }^{3}$ decision simply because the test scores of black students have not improved as quickly as society thinks they should. Nevertheless, a clearer understanding of the research on desegregation's effects on achievement may have some impact on policy matters. More important, an analysis of existing research suggests optimal strategies for desegregation-for example, at which grade levels desegregation is more likely to have a positive effect on the test scores of blacks.

2. Only a few studies have found that test scores of white students improved after desegregation. See, e.g., Stallings, $A$ Study of the Immediate Effects of Integration on Scholastic Achievement in the Louisville Public Schools, 28 J. Negro Educ. 439, 442-43 (1959); R. Mayer, C. King, A. Borders-Patterson, \& J. McCullough, The Impact of School. Desegregation in a Southern City 87-94 (1974). A few others found that the test scores of white students declined. See., e.g., D. Catherine Baltzell, Rapid Desegregation and Academic Achievement in a Large Urban School District (paper presented at the annual meeting of the American Education Research Association, April 1974, in Chicago, Illinois) (ERIC Document No. 090 282); Justin \& Thabit, Black and White Achievement Before and After Integration, 102 InTELlect 458 (1974); Kurtz, An Independent Assessment of "Integration in Evanston, 1967-1971: A Longitudinal Evaluation": A Report of the Educational Consequences of Desegregation in District 65 of Evanston, Illinois, Hearings on School Busing, Part 3, Before the House Comm. on the Judiciary, Subcomm. No. 5, 92d Cong., 2d Sess., 1436, 1437 (1972). The majority, however, found no significant change. See, e.g., N. St. John, School Desegregation: OUtCOMEs FOR ChILDREN (1975), listing 23 studies of white achievement after desegregation, of which only 5 show consistent effects ( 2 positive, 3 negative).

3. Brown v. Board of Educ., 347 U.S. 483 (1954). 


\section{The Research Studies Reviewed}

\section{A. Studies of "Natural" versus "Intentional" Desegregation}

The major input-output analyses of achievement test performance, including the frequently cited Coleman Report, ${ }^{4}$ are not reviewed in this article for two reasons. First, a good review of this material is now being completed and there seems no reason to duplicate it. ${ }^{5}$ Second, the issues studied in this type of research are somewhat different from those in the other studies, so it is useful to keep them separate. The input-output research focuses on school racial composition rather than the type of desegregation as the independent variable. Most of the racially mixed schools in the United States result from what is sometimes called natural desegregation: the assignment to neighborhood schools of students from mixed neighborhoods or from adjoining segregated neighborhoods. Therefore, the input-output studies are evaluating the effect of long-term desegregation, unaffected by public controversy or any impact of busing. In contrast, the other studies of desegregation have, almost without exception, been undertaken during the first two years after a desegregation plan has been implemented. Intentional and natural desegregation are in the long run probably indistinguishable, but the impact of the first two years of intentional desegregation may be different from long-term natural desegregation effects.

A recent review of the input-output studies concludes that there is no relationship between white academic performance and school racial composition, and that, with one exception, black achievement test performance is higher in predominantly white schools. ${ }^{6}$ One input-output study of a very large sample-the National Longitudinal Study (NLS) of the 1972 high school senior class ${ }^{7}$ - has examined the relationship between school racial composition

4. J. Coleman, E. Campbell, C. Hobson, J. McPartland, A. Mood, F. Weinbeld, \& R. York, Equality of Educational OpPortunity (1966) [hereinafter cited as Coleman RePort].

5. G. Bridge, C. Judd, P. Moock, The Determinants of Educational. Outcomes: The Effects of Families, Peers, Teachers, and Schools (forthcoming).

6. Id. The one exception involves a California school district where a negative effect was found for students who went to predominantly white junior high schools from black elementary schools, but a positive effect for those black students who had attended predominantly white elementary schools before entering junior high school. Winkler, Educational Achievement and School Peer Group Composition, 10 J. Human Resources 189, 198-99 (1975). This finding suggests that delaying desegregation until the sixth grade is dysfunctional. See discussion infra pp. 34-38.

7. National Longitudinal Study of the High School Graduating Class of 1972, described in $W$. Fetters, National longitudinal Study of the High School Class of 1972: Comparative Profiles One and One-Half Years After Graduation (1975) [hereinafter cited as W. Fetters, National Longitudinal Study]. See also McPartland, Desegregation and Equity in Higher Education and Employment: Is Progress Related to the Desegregation of Elementary and Secondary Schools?, 42 LAw \& 
and black achievement in the North and the South separately. ${ }^{8}$ Analysis of the Northern data shows a significant positive relationship between the percentage of white students attending the school and black achievement. However, in the South, black students who attend predominantly white schools do not have higher achievement scores than those who attend all-black schools. ${ }^{9}$ The difference in achievement scores between those who attended all-black and those who attended predominantly white schools is shown in Table 1.

TABLE 1 Black School-Level Achievement Test Scores by High School
Percentage White and Region, Statistically Controlled for
Socioeconomic Status (SES) and School District Size

\begin{tabular}{cccc}
\multicolumn{2}{c}{ South } & \multicolumn{2}{c}{ North } \\
School Percent & White & School Percent White \\
$0 \%$ & $90 \%$ & $0 \%$ & $.90 \%$ \\
41.63 & 41.90 & $42.30^{\circ}$ & $45.99^{\circ}$
\end{tabular}

Mean Black Achievement

$\circ \mathrm{p}<.05$

NoTE: Percentages are derived from a regression equation in which mean black SES, school district size, and school percentage white are used to predict mean black achievement. Black achievement is reported in standard scores (i.e., $\overline{\mathrm{X}}=50, \sigma=10$ ), and achievement scores are computed from the equations by entering $0 \%$ and $90 \%$ as values of percent white.

Source: Crain \& Mahard, School Racial Composition and Black College Attendance and Achievement Test Performance, 51 Soc. of Educ., April 1978, at 88.

The foregoing input-output studies present some methodological problems, including that of how to control for background factors. In most of these studies, the black students who attend predominantly white schools are of higher socioeconomic status than those in segregated schools. When this is the case, the use of a pretest score or a measure of socioeconomic status as a control does not remove all of the differences in achievement related to background. There are various potentially helpful statistical techniques, but ultimately the only answer is perfect measurement of all variables, which is of course impossible. A second problem is that of bias due to self-selection. If black parents who move into integrated neighborhoods are more motivated to advance the achievement of their children than parents who remain in segregated neighborhoods, a bias is introduced that cannot be easily eliminated. ${ }^{10}$

Contemp. Prob., Summer 1978, at 123-24 for a discussion of the study. The NLS surveyed 23,000 students in 1,000 schools.

8. Crain \& Mahard, School Racial Composition and Black College Attendance and Achievement Test Performance, 51 Soc. OF Evuc., A.pril 1978, at 81, 86-88.

9. Id.

10. The analysis of the NLS data, supra note 7 , by Crain and Mahard found no evidence that the higher achievement of Northern blacks who attended predominantly white schools compared 
Despite these methodological difficulties, the consistent finding of these input-output studies, which use a variety of methodologies and analyze a variety of data sets, is that black achievement is higher in predominantly white schools. These analyses of so-called natural desegregation fulfill a function that no evaluation of a particular desegregation plan can duplicate. Even the most carefully designed evaluation provides information about only one school system and the effects of the first year or two of desegregation. Inputoutput studies, on the other hand, can measure the long-term effects of desegregation, and in the case of two such studies, provide averages of such effects across a large number of districts. ${ }^{11}$

The conflict over the effects of desegregation will not be resolved by further input-output studies not only because of the methodological problems already noted, but also because of the failure to agree upon how large an effect must be before it can be considered positive. ${ }^{12}$ If the standard is closing the black-white achievement gap, then desegregation has failed. ${ }^{13}$ But we think this is an unreasonable standard; the black-white achievement gap will not disappear overnight. Assuming that the relationship between racial composition and achievement found by these input-output studies is not due to methodological error, it seems absurd to dismiss desegregation on the basis that it will raise black student achievement by "only" one grade level (which makes it a more effective tool for improving black student academic performance than any curriculum innovation or other educational treatment yet devised by educators and researchers).

A review of studies of particular desegregation plans will complement the review of input-output studies now underway. ${ }^{14}$ Analyses of desegregation plans can sometimes control for differences in socioeconomic status and for self-selection more carefully than the input-output studies can. Also, if the input-output studies are correct in indicating a long-term positive effect of desegregation on black achieyement, it is worthwhile to analyze the process by which that long-term effect is attained. Finally, a comparison of different desegregation plans can provide information on which strategies are most effective.

to those who attended all-black schools was a result of self-selection. Crain \& Mahard, supra note 8, at 90-98. However, the problem of self-selection bias requires more work.

11. Coleman Report, supra note 4; W. Fetters, National Longitudinal Study, supra note 7.

12. For these reasons we think no more than a small part of the current conflict will be settled by publication of the analyses undertaken by G. BRIDGE, C. Judd, \& P. Moock, supra note 5.

13. One study has concluded that the Coleman Report indicated that no more than one-fifth of the black-white gap in achievement will be eliminated as a result of desegregation. Cohen, Pettigrew, \& Riley, Race and the Outcomes of Schooling, in ON EQuality Of Educational OpportuNITy 343, 358 (Mosteller \& Moynihan eds. 1972).

14. See G. Bridge, C. Judd, \& P. Moock, supra note 5. 
The short-term desegregation evaluations do not show results as consistently positive as those found in the long-term studies, in part because they are not as methodologically sound. But we also suspect that if desegregation occurs under certain conditions, the short-run effects will not be positive. Student performance can be affected by community conflict, by school desegregation that is not reinforced by neighborhood integration, and by the racial attitudes of black and white students and staff. For example, desegregation may have a short-term negative effect if teachers do not adapt their teaching methods to their new students, or if black students do not make the transition to a white school easily and are upset by racial issues or simply by the change in schools. Thus, a review and comparison of various studies of specific desegregation plans should indicate which characteristics of desegregation plans are most likely to result in immediate positive achievement effects. This question is the primary motivation for this analytical review.

\section{B. The Sample of Studies Reviewed}

The authors have identified approximately 100 studies of the effects of desegregation and black achievement. Of these 100 studies, 41 were obtained and reviewed by the authors, ${ }^{15}$ and 32 have been reviewed by either Nancy St. John ${ }^{16}$ or Meyer Weinberg ${ }^{17}$ in their earlier reviews of the desegregation

15. The 41 studies represent data from 35 desegregation plans by 38 different authors. Two different authors study the same plan in three cases: Armor, The Evidence on Busing, 28 PuB. INTEREST 90 (1972) and Herbert Walberg, An Evaluation of an Urban-Suburban School Busing Program: Student Achievement and Perception of Class Learning Environment (paper presented at the annual meeting of the American Education Research Association, February 1971, in N.Y., N.Y.) (ERIC Document No. 047 076); Jayjia Hsia, Integration in Evanston, 1967-1971: A Longitudinal Evaluation (Educational Testing Service Report, August 1971) and Kurtz, supra note 2; F. Aberdeen, Adjustment to Desegregation: A Description of Some Differences Among Negro Elementary School Pupils (1969) (unpublished Ed.D. dissertation, University of Michigan) and Patricia Carrigan, School Desegregation via Compulsory Pupil Transfer: Early Effects on Elementary School Children (report to Ann Arbor Public Schools, September 1969) (ERIC Document No. 036 597). In three other cases, a study was treated as two separate studies, once because different methodologies were used at different grade levels, R. Mayer, C. King, A. BordersPatterson, \& J. McCullough, supra note 2; and twice, because different results were obtained in different schools or in different years of a continuing evaluation. Charles Evans. Short-term Desegregation Effects: The Academic Achievement of Bused Students, 1971-72 (report to Fort Worth Independent School District, 1973) (ERIC Document No. 086 759) [hereinafter cited as Short-term Desegregation Effects], Charles Evans. Integration Evaluation: Desegregation Study II-Academic Effects on Bused Black and Receiving White Students, 1972-73 (report to Fort Worth Independent School District, 1973) (ERIC Document No. 094 087) (hereinafter cited as Integration Evaluation], Syracuse City School District, Study of the Effect of Integration-Croton and Edward Smith Elementary School Pupils, in U.S. Comm's on Civil Rights, Hearing Held IN Rochester, New York, September 16-17 (1966) [hereinafter cited as Syracuse City School District, Croton and Edward Smith Elementary School Pupils], and Syracuse City School District, Study of the Effect of Integration-Washington Irving and Host Pupils, U.S. Comm'N on Civil Rights, Hearing Held in Rochester, New York, September 16-17 (1966) [hereinafter cited as Syracuse City School District, Washington Irving and Host Pupils].

16. N. ST. John, supra note 2.

17. M. Weinberg, Minority Students: A Research Appraisal (1977). 
research literature, making a total of 73 studies analyzed in this article. ${ }^{18}$ This sample is limited to studies of specific desegregation plans. Studies of school integration resulting from residential integration are ignored on the assumption that they provide no more information than the generally better quality input-output studies do.

This article owes a great debt to the extensive bibliography prepared by Meyer Weinberg. ${ }^{19}$ However, even this bibliography is incomplete. There is surprisingly little overlap between the St. John and Weinberg bibliographies, suggesting that the eighty-seven citations culled from Weinberg for this study may be as little as one-half of the available literature. Even after the inadequate studies and those that duplicate other reports are eliminated, there may be as many as 200 studies in the United States. This is a fugitive literature. Of the forty-one studies the authors have obtained, only sixteen are published in scholarly journals and books. The remainder are unpublished reports and doctoral dissertations. ${ }^{20}$

For the purposes of this review of the research, each of the seventy-three studies that comprised the sample was coded according to the following:

1. The demographic characteristics of the community.

2. The type of desegregation plan.

3. The methodology used in the research.

4. The racial composition of schools before and after desegregation.

5. The grade levels of desegregated students.

6. The direction of the achievement effect, and its magnitude expressed as change in either grade equivalents or standard scores, and reports of any interaction effects in the data (e.g., a finding that desegregation effects are stronger at one grade than another).

7. The presence of special programs to improve the quality of education or to prepare students or staff for desegregation.

8. The source of research funding, the position held by the researchers, and the form of publication.

The strategy of this ongoing study is to examine the relationship between achievement and the type of desegregation plan, the degree of school or staff preparation for desegregation, and the characteristics of the students involved. An important aspect of the study will be to test hypotheses about bias (for example, whether academic researchers fail to publish negative findings).

18. These studies, reviewed by Weinberg, St. John, or the authors, are listed in the appendixes.

19. M. WEINBERG, supra note 17 .

20. Many of these studies are not available in the ERIC library. 
In the present article, only two questions are addressed:

1. What is the average effect of desegregation on black achievement?

2. What are the effects of age of student, region of the country, and voluntary versus mandatory pupil reassignment on black achievement?

Of the seventy-three research studies analyzed for this article, forty find that desegregation has a positive effect on black achievement, and only twelve show a negative result: positive findings outnumber negative findings by a ratio of three to one. The agreement between these studies and the inputoutput research is encouraging, although some will undoubtedly argue that the achievement gains are usually small compared to the size of the overall black-white achievement gap. No comprehensive statement can be made about the magnitude of these effects of desegregation, since many of the studies do not provide sufficient information to permit the effects to be converted into either standard score differences or grade equivalents.

The forty-one studies reviewed by the authors are a biased sample of the seventy-three, since they include somewhat fewer studies with positive findings and more studies with negative results than are found in the thirty-two studies reviewed by St. John or Weinberg. This is partly because we have interpreted some small differences as negative rather than as zero. A comparison of the results of the studies reviewed by the authors with the results of those reviewed by Weinberg and St. John is given in Table 2.

\section{TABle 2}

Number of Studies with Positive, Zero, on Negative Effects on Desegregation Reviewed by the Authors or by St. John and Weinberg

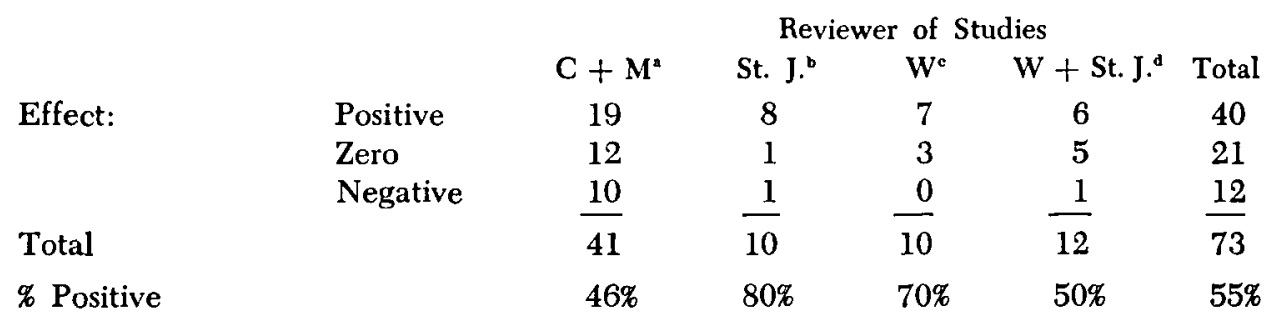

atudies reviewed by the authors.

'Studies not received by the authors at press time but reviewed by Nancy St. John, in N. St. John, School Desegregation: Outcomes for Children (1975).

"Studies not received by the authors at press time but reviewed by Meyer Weinberg, in M. Weinberg, Minority Students: A Research Appraisal (1977).

$\mathbf{d} \mathbf{b}+\mathbf{c}$. 


\section{Methodological Issues}

Optimum evaluation research follows the experimental model. The experiment is as simple as it is effective, consisting of only three basic steps. First, the population is randomly divided into two groups. Second, a treatment is administered to one of the two groups and not the other, and third, a measurement is made. If there is a difference between the two groups at the end of the experiment, the difference can almost always be assumed to have been caused by the treatment. One serious problem with applying the experimental model to desegregation is that the treatment in this case is of thirteen years duration and no one thus far has been willing to wait that long to publish his results. There are also serious questions about whether the standardized achievement test is the correct measure of cognitive outcomes.

Experimental research can be hard to execute-in some cases, impossible. A mandatory desegregation plan that reassigns every student cannot normally be designed to exclude some students randomly. But there are many cases when experimental design is possible, and at least two studies have used one. The two designs differed only slightly. In both cases, black students in an inner-city school system volunteered to attend predominantly white schools in the suburbs. In the first study, by Mahan and Mahan, ${ }^{21}$ a group of inner-city classrooms was identified, and twelve classrooms were selected by a table of random numbers. ${ }^{22}$ A subsample of the unselected classrooms was used as the control group. Parents of the treatment group were notified, and their cooperation was requested. Ninety-six percent of the parents agreed to permit their child to attend suburban schools. Thus, although this was a voluntary project, for research purposes it differed little from a mandatory reassignment except for the 4 percent who refused. The second study, by $\mathrm{Zdep},{ }^{23}$ is more conventional: parents were asked if they wanted to send their children to suburban schools voluntarily, and a random sample of treatment and control students was selected from among the volunteers. Refusing some volunteers was possible in this case because the suburban school was only willing to accept a limited number of students. ${ }^{24}$

When a true experimental design cannot be employed, the next best

21. Mahan \& Mahan, The Impact of Schools on Learning: Inner-City Children in Suburban Schools, 9 J. Sch. Psych. 1, 3 (1971).

22. To help the study's legitimacy, the lottery was conducted by minority leaders.

23. Zdep, Educating Disadvantaged Urban Children in Suburban Schools: An Evaluation, 1 J. APPlied Soc. Psych. 173, 174-76 (1971).

24. Both studies used achievement test scores obtained prior to assignment to the white suburban schools. This control on achievement scores prior to desegregation eliminated a good deal of variance in the dependent variable, meaning that effects were more likely to be significant with this small sample size. However, a pretest is not necessary; a cross-sectional analysis is sufficient when students are randomly selected. See D. Campbell \& J. STanley, Experimental and QuasiExperimental Design for Research 2 (1966). 
alternative is a study in which an approximation of a random process has occurred. The best example of this is the research of Schellenberg and Halteman in Grand Rapids, Michigan. ${ }^{25}$ In this case, students were reassigned from inner-city schools to white suburban schools to relieve overcrowding, and the students designated for reassignment were those who lived in areas farthest from their neighborhood schools. Schellenberg and Halteman argued that there was no reason to assume that students who lived in the same general residential area differed in any significant way. In effect, the control group consisted of those who lived a few blocks nearer their local school than the experimental (bused) group had. ${ }^{26} \mathrm{~A}$ similar argument can be made with regard to Evans's research on desegregation in Fort Worth. ${ }^{27} \mathrm{~A}$ map of the Fort Worth desegregation plan indicates that the areas included in the plan are widely scattered throughout the city and seem to have been chosen mainly for geographical reasons rather than because of any student characteristics.

A considerably weaker design is the conventional longitudinal design with students matched on pretest scores or on socioeconomic status. One problem is that in a voluntary plan there is a serious possibility of self-selection bias. This is especially true if the volunteers represent only a small fraction of the total student population available. Students attending desegregated schools are more likely to have parents who are interested in desegregation, or interested in their child's school performance, or simply more likely to have heard about the plan. Various devices have been used to match students to an artificial control group under these circumstances, but none of these techniques is infallible. Walberg ${ }^{28}$ and Armors ${ }^{29}$ each evaluated the Boston METCO Plan $^{30}$ using siblings of the transferred students as the control group. The argument for sibling matching is that home environment factors and the gene pool are controlled. But this may not be a good solution, since sibling controls virtually maximized the possibility of self-selection bias. Parents chose to bus one of their children but not another. Presumably they did so because of feelings about the differences between their children. We do not know whether the parents would usually select the child most likely to succeed in school or the child having the most difficulty. In either case, a bias has been introduced.

\footnotetext{
25. Schellenberg \& Halteman, Busing and Academic Achievement, 10 URB. E Duc. 357 (1976).

26. Id. at 360 .

27. Charles Evans, Short-term Desegregation Effects, supra note 15; Charles Evans, Integration Evaluation, supra note 15.

28. Herbert Walberg, supra note 15.

29. Armor, supra note 15.

30. The voluntary METCO program was begun in 1966 to bus black students of all grade levels from predominantly black city schools in Boston to predominantly white middle-class schools in the surburbs. The control group consisted of siblings of the bused students who were matched with the bused students by sex and grade level.
} 
A second problem with research studies that use the conventional longitudinal design also confronts the input-output studies: ${ }^{31}$ if the two groups are not identical in social class or ability, the use of a pretest score or a measure of socioeconomic status as a control will not eliminate these differences entirely. A final problem with all studies using control groups is that a control group may not exist. Again, one can take desperate measures, though they may be ineffective or self-defeating. For example, Carrigan, in her study of school desegregation in Ann Arbor, Michigan, ${ }^{32}$ used as her control group black students who were not reassigned for desegregation purposes. Unfortunately for the research, the reason they were not reassigned is that they were already attending a school that was 50 percent white.

Cross-sectional studies that do not use pretests but instead use black students attending a segregated school as a control are also possible. These have a disadvantage compared to longitudinal studies in that measures of socioeconomic status are not as good at predicting achievement as are pretest achievement scores. Consequently, the cross-sectional studies have a weaker control variable. Their advantage is that they are lower in cost, lend themselves to studies across a number of school districts simultaneously, and permit the researcher to administer the achievement test, thereby controlling the testing situation.

While it is possible to study the effects of desegregation without a control group comprised of black students who attend segregated schools, the absence of such a control group makes the research problems more critical and complex. Districts in which all students are reassigned to desegregated schools must be analyzed by comparing the performance of the reassigned black students with that of a cohort, with that of white students, or with national norms. A cohort study seeks to determine whether black students in a particular grade after reassignment are performing better or worse than black students who were in the same grade before desegregation, that is, in an earlier cohort. The necessary assumption is that the students in the two cohorts are similar-that there has been no external trend in the student population over time. More importantly, the cohort study design assumes there is no difference in the testing conditions between the two years. These conditions obviously were not met in at least some of the studies reviewed for this article. Aberdeen's study of the effect of the desegregation of the Ann Arbor schools found a decline in achievement test scores over time. ${ }^{33}$ However, Carrigan's analysis of the same data showed that in one year IQ scores of black students in the school district jumped nearly five points. ${ }^{34}$ It is doubtful whether either

\footnotetext{
31. See discussion in text at note 10, supra.

32. Patricia Carrigan, supra note 15, at 21.

33. F. Aberdeen, supra note 15.

34. Patricia Carrigan, supra note 15 , at 108.
} 
the increase in the IQ scores or the decline in achievement test scores should be trusted. A reanalysis of data from Evanston, Illinois showed that while black achievement scores declined steadily after desegregation, there was a similar decline in the scores of white students, suggesting that something other than desegregation was involved. ${ }^{35}$

The weakest possible research design involves a comparison of the postdesegregation achievement scores of black students with those of white students in the same district or with national norms. In the latter case, this may mean merely a comparison of the test scores of the black students with those of a virtually unknown and probably nonrandom sample used by the test manufacturer. Even under the most careful statistical controls, it is difficult to interpret the results of such comparisons. For example, Perry's study of the talented black students who received scholarships to elite private schools under the ABC (A Better Chance) Program in Boston found that black achievement scores did not go up. ${ }^{36}$ Perry compared black and white students who attained the same scores on their ninth grade tests. When both groups were tested in the twelfth grade, however, the black students performed less well than their white classmates did. Perry was, of course, well aware of the inadequacy of this evidence, given that, under normal conditions, the black-white achievement gap increases with age. ${ }^{37}$

It must not be assumed that methodological weaknesses in a study always tend to produce false positive results. If the methodological weakness is the inability to control adequately for sharply differing pretest conditions between the treatment and the control group, pretest differences are likely to persist, producing a false positive or negative result. If the error is inadequate control for either the known independent national decline in achievement occurring over the past few years, or the known increase with age in the achievement gap between blacks and whites, then a false negative result is more likely. Of the three studies that compared black to white achievement, only one produced a positive result. ${ }^{38}$ Of five studies that compared black student per-

35. Kurtz, supra note 2.

36. B. Perry \& N. Kopperman, A Better Chance: Evaluation of Student Attitudes and Academic Performance, 1964-1972 (1973) (ERIC Document No. 075 556).

37. Perry attempted to construct a control group of black applicants who were not admitted to the program because of limited space, but he was unable to find sufficient numbers of such students.

38. The study showing a positive result is Denmark, The Effect of Integration on Academic Achievement and Self-Concept, 8 Inregrated EDuc. 34 (1970). The other two studies show a constant black-white achievement difference before and after desegregation. Beers and Reardon argue that this result should be interpreted as a positive effect, given that racial differences in achievement levels usually increase with age. Beers \& Reardon, Racial Balancing in Harrisburg: Achievement and Attitudinal Changes, 12 InTEGRATEd Educ. 35 (1974); Harry Singer, Effect of Integration on Achievement of Anglos, Blacks, and Mexican-Americans (paper presented at the annual meeting of the American Education Research Association, March 3-6, 1970, in Minneapolis, Minnesota) (ERIC Document No. 041 975). 
formance after desegregation with national norms, three found negative results. $^{39}$ The same pattern occurs with the cohort studies. Only three of the eight cohort studies that compared black performance after desegregation to the performance of students in the same grade before desegregation found a positive outcome. ${ }^{40}$ In other words, the studies that compare the performance of reassigned black students with that of a cohort, or that of white students, or with national norms produced half of the negative findings in the fortyone studies reviewed by the authors, but only one-third of the positive findings.

In reviewing the forty-one studies, the strongest methodological test was extracted from each study. Frequently, several different tests of the achievement effect were done; the one we judged to be the strongest design is reported. For example, if the study reported a comparison of the achievement of desegregated black students both with national norms and with that of a previous cohort, the latter design is used in this analysis. In some cases, the stronger design was flawed, and a theoretically weaker design was considered to be the better. For example, we discarded Carrigan's control group in our analysis because it consisted of black students attending a biracial school and used her cohort comparison instead. ${ }^{41}$

\section{General Comments on the Sample and on School Desegregation Research}

There are a number of excellent studies included in this review of the research that merit recognition. The Mahan and Mahan study of the Hartford Experiment ${ }^{42}$ and the Zdep study of Newark and Verona, New Jersey, ${ }^{43}$ are carefully executed research designs. The Teele study of Operation Exodus in Boston is impressive because of the author's attempts to outwit an intractable

39. F. Aberdeen, supra note I5; B. Perry \& N. Kopperman, supra note 36; Carolyn Thompson \& Frances Dyke, First Interim Evaluation Report: Urban-Suburban Pupil Transfer Program 1971-1972 (report to Rochester City School District, August 1972) (ERIC Document No. 068 609) found negative results. Two studies found black students gaining ground with respect to national norms. Maynor \& Katzenmeyer, Academic Performance and School Integration: A Multi-Ethnic Analysis, 43 J. Negro Educ. 30 (1974); R. Mayer, C. King, A. Borders-Patterson, \& J. McCullough, supra note 2.

40. Among the eight cohort studies are two with negative results: Justin \& Thabit, supra note 2; Kurtz, supra note 2. Three produced results of zero: Patricia Carrigan, supra note 15; Arthur Dambacher, A Comparison of Achievement Test Scores Made by Berkeley Elementary Students Pre and Post Integration Eras, 1967-1970 (mimeographed report for Berkeley Unified School District, 1971); and H. Gerard \& N. Miller, School Desegregation: A Long-Term Study (1975). Three studies produced positive results: Prichard, The Effects of Desegregation on Student Success in the Chapel Hill Schools, 7 Integrated Educ, 33 (1969); J. Teele, Evaluating School Busing: A Case Study of Boston's Operation Exodus (1973) (also ERIC Document No. 083 334); and Clark County School District, Desegregation Report (Clark County School District report, Las Vegas, Nevada, July 1974) (ERIC Document No. 106 397).

41. See text at note 32 supra.

42. Mahan \& Mahan, supra note 21.

43. Zdep, supra note 23; M. WEINBERG, supra note 17 , at 122. 
environment and produce a successful evaluation where most people would have given up. ${ }^{44}$ Another study that deserves attention is Schellenberg and Halteman's analysis of desegregation in Grand Rapids, Michigan, because more than any other study, it shows an attention to the logic of the control group comparison where randomization is absent. ${ }^{45}$ The Evans analysis of Fort Worth ${ }^{46}$ and the evaluation of Goldsboro by Mayer, King, BordersPatterson, and McCullough ${ }^{47}$ are outstanding because of the completeness of the data-even maps of the desegregation plan are included. The Goldsboro report analyzes the desegregation planning process, community reaction, the logistics of the desegregation plan, staff preparation, reactions of students to each other, and changes in teaching methods. It is relevant to note that the four authors of this most comprehensive single evaluation of desegregation are a white professor of city planning, a black sociologist, a black testing expert, and a white psychologist. The diversity of race and disciplines is no doubt important to good research.

The experimental tradition in psychology has been a source of both the strengths and the weaknesses of desegregation research. That tradition has provided a sophisticated methodology for desegregation research, but in going from the laboratory to the real world we have lost control of the intervention. No two desegregation plans are alike; there is little reason to expect a uniform treatment effect of desegregation. The common error of this research can be stated in six words: Desegregation is not an educational treatment.

The authors of this article believe this explains why so many of the aspects of desegregation plans that need to be examined are not discussed in these studies. One problem is the absence of studies of the effects of desegregation past the second year. In general, however, our dissatisfaction stems not from the inadequacies of the design but from the inadequacy of the research reporting. For example, it would be useful to know if there is an optimal racial composition for the desegregated school, but three-quarters of the studies do not report the racial composition of the schools either before or after desegregation. It would be useful to know the relationship of different socioeconomic mixes to the impact of desegregation on achievement; again, there are usually no data. There is almost never any information on the school curriculum, staff racial composition, teacher attitudes, staff preparation, special school programs, or community reactions included in the evaluations of desegregation effects. Data on teacher racial behavior would seem to

\footnotetext{
44. J. TEELE, supra note 40.

45. Schellenberg \& Halteman, supra note 25.

46. See note 27 , supra.

47. R. Mayer, C. King, A. Borders-Patterson. \& J. McCullovgh, supra note 2.
} 
be especially important since several recent studies have suggested that the negative racial attitudes and behaviors of teachers have a harmful effect on black student attitudes and achievement. ${ }^{48}$

\section{Factors Influencing the Success of Desegregation Plans}

\section{A. The Effect of Region}

A clear regional pattern, shown in Table 3, is demonstrated by the fortyone studies reviewed for this article. Two-thirds of the Southern studies show positive outcomes, compared to only 35 percent of the Northern studies. This result is tentative, at best, since it is not supported by the data from the thirtytwo other studies that St. John and Weinberg have reviewed. The studies reviewed by St. John and Weinberg also showed significant positive gains in the South, but differed from the forty-one studies we reviewed in that they also showed a generally positive outcome in the North. It is possible that when these thirty-two other studies are combined with the studies we reviewed, the North-South difference indicated by our analysis will be greatly reduced.

\section{TABLE 3}

Overall Desegregation Effects of Reviewed Studies, by Region

\begin{tabular}{llccc} 
& & \multicolumn{2}{c}{ Region } & \\
Effect: & North & South & Total \\
& Zeritive & 9 & 10 & 19 \\
Total & Negative & 11 & 1 & 12 \\
\% Positive & & $\frac{6}{26}$ & $\frac{4}{15}$ & $\frac{10}{41}$ \\
& & $35 \%$ & $67 \%$ & $46 \%$
\end{tabular}

It is safe to conclude at this point, however, that the short-term impact of desegregation in the South is not a negative one. Ten of the fifteen Southern

48. See, e.g., R. Crain, Southern Schools: An Evaluation of the Effects of School Desegregation and of the Emergency School aID Program (National Opinion Research Center Report Nos. 124A, 124B, October 1973) (ERIC Document Nos. 085 426, 085 427); J, Coulson, D. Ozenne, S. Hanes, C. Bradford, W. Doherty, G. Duck, \& J. Hemenway, The Third Year of Emergency School Aid Act (ESAA) Implementation (March 1977) (ERIC Document No. 154 952); G. Forehand, M. Ragosta, \& D. Rock, Conditions and Processes of Effective. School Desegregation (1976) (ERIC Document No. 131 155); J. Wellisch. R. Carriere. A. MacQueen. \& G. Duck, An In-Depth Study of Emergency School Assistance Act Schools 1975-1976 (1977) (ERIC Document No. 133 361); Felice. The Effects of School Desegregation on Minority Group Student Achievement and Self-Concept: An Evaluation of Court Ordered Busing in Waco, Texas (1974) (ERIC Document No. 094 096); and H. Gerard \& N. Miller, supra note 40 . 
studies in the sample indicated that desegregation produces short-term positive gains. Analysis of the five deviant studies showed them to have more methodological weaknesses than did the ten studies showing positive results. Among the studies indicating that desegregation has a short-term negative impact on black student achievement is Stallings's 1955 study of Louisville ${ }^{49}$ after the first year of desegregation, which found that black students who chose to remain with black teachers gained more than the blacks who did not so choose. But scores of both groups went up compared to the preceding year, as did white students' scores; ${ }^{50}$ it is hard to argue that desegregation has a negative effect when scores go up. Justin and Thabit ${ }^{51}$ found a decline in the test scores of black students after desegregation in Florida, but this study involved a cohort comparison and was accompanied by a white decline as well-a result exactly the opposite of that found by Stallings. These results suggest that the test situation may have changed or that there was a general secular decline in performance at the same time, independent of desegregation. Felice's study of Waco, Texas, ${ }^{52}$ found a negative impact on achievement, but his sample was small (only fifty-five students in the control group). In addition, although his control group was matched to the treatment group in terms of their previous achievement levels, they were mismatched on age, grade, and sex, which may have influenced the results. Fortenberry's study of desegregation in Oklahoma, ${ }^{53}$ limited to the eighth and ninth grades, was apparently ambushed by unusual differences in the curriculum provided in the black and white schools. ${ }^{54}$ Of the five studies showing non-positive results, only a study of Dade County desegregation ${ }^{55}$ found a decline in the achievement of black students who were reassigned to white schools. Much of the apparent loss due to desegregation can be attributed to a gain over time among black students in segregated schools.

The ten Southern studies that found positive results seem stronger methodologically. These include the two Fort Worth studies ${ }^{56}$ and the study by Mayer and his co-workers. ${ }^{57}$

The proposition that methodological differences account for some of the negative results in the Southern studies can be tested in one other way. There

49. Stallings, supra note 2 , at 439,443 .

50. Id.

51. Justin \& Thabit, supra note 2 .

52. Felice, supra note 48 .

53. James Fortenberry, The Achievement of Negro Pupils in Mixed and Non-Mixed Schools (1959) (unpublished Ed.D. dissertation, University of Oklahoma).

54. See discussion infra pp. 39-40.

55. Robert Stephenson and Phillip Spieth, Evaluation of Desegregation 1970-1971 (Dade County Public Schools Department of Program Evaluation report, June 1972) (ERIC Document No. 070 792) [hereinafter cited as Dade County Evaluation].

56. Charles Evans, Short-term Desegregation, supra note 15; Charles Evans, Integration Evaluation, supra note 15 .

57. R. Mayer, C. King, A. Borders-Patterson, \& J. McCullough, supra note 2. 
is evidence that evaluations done at the end of one year of desegregation are less likely to be favorable than those undertaken after two years. Of the seven evaluations done at the end of the first year of desegregation, three obtained negative results; ${ }^{58}$ of the seven done at the end of the second year or later, six were positive. ${ }^{59}$ Therefore we can hypothesize that the Southern results would be even more positive if all the evaluations had been done after the second year.

These data indicate that desegregation in the South has resulted in consistently positive outcomes, a finding in accord with the findings of the Northern input-output studies of school racial composition. ${ }^{60}$ It is not, however, consistent with the input-output analysis of the National Longitudinal Study's Southern data, which showed that black students who attended predominantly white schools did not have higher achievement scores than those who attended all-black schools. ${ }^{61}$ This discrepancy can be explained by the fact that the National Longitudinal Study data are on twelfth graders only. These students had experienced only two or three years of desegregation in 1972. It is widely believed, however, that desegregation may not show positive effects until a longer period of time has elapsed. It is also frequently argued that desegregation, to be successful, should occur in the early grades, ${ }^{62}$ yet few black seniors attending a Southern high school in 1972 were likely to have attended desegregated elementary schools. All of this suggests that there was insufficient time for positive effects to appear when the 1972 survey was undertaken. This conclusion is supported by the findings of the $1976 \mathrm{Na}$ tional Assessment of Educational Progress, which found that between 1969

58. The studies conducted at the end of the first year of desegregation that obtained positive results are: D. Catherine Baltzell, supra note 2; Charles Evans, Short-term Desegregation, supra note 15; Frary \& Goolsby, Achievement of Integrated and Segregated Negro and White First Graders in a Southern City, 8 InTEgrated Educ. 48 (1970); and Maynor \& Katzenmeyer, supra note 39. Three other one-year studies found negative results: Justin \& Thabit, supra note 2; Stallings, supra note 2; and Dade County Evaluation, supra note 55.

59. Among studies done at the end of two or more years of desegregation, only Felice's presents negative results. Felice, supra note 48. Positive results are reported in: Louis Anderson, The Effect of Desegregation on the Achievement and Personality Patterns of Negro Children (1966) (unpublished Ph.D. dissertation, George Peabody College for Teachers); Charles Evans, Integration Evaluation, supra note 15; R. Mayer, C. King, A. Borders-Patterson, \& J. McCullovgh, supra note 2 (also in the results from Mayers's study of the ninth grade students, which we coded separately because it had no control group); Prichard, supra note 40; and Frank Williams, An Analysis of Some Differences Between Negro High School Seniors from a Segregated High School and a Nonsegregated High School in Brevard County, Florida (1968) (unpublished Ed.D. dissertation, University of Florida). The one study that obtained a zero result, James Fortenberry, supra note 53, did not specify the duration of desegregation. The gamma between years of desegregation at posttest and desegregation outcomes is +.55 .

60. See discussion at text accompanying notes 6-9. supra.

61. Crain \& Mahard, supra note 8 , at $86-88$.

62. See discussion infra pp. 34-38. One study goes even further and suggests that it is actually detrimental to the achievement of black students if their first desegregation experience does not occur until after the sixth grade. Winkler, supra note 6, at 189, 202. 
and 1973 the achievement of Southern black nine-year-olds went up, while the achievement of nine-year-olds for the nation as a whole declined ${ }^{63}$ The white-black achievement gap decreased for this age group in the South but not for thirteen- or seventeen-year-olds. The achievement gap increased for nine-year-olds in the North. At the same time, the achievement levels of Southern whites did not increase over those of Northern whites. ${ }^{64}$ We do not know if the increase in the achievement levels of black nine-year-olds is due to desegregation, although the first substantial desegregation of the South occurred during that time. ${ }^{65}$ At about the same time, the quality of schooling available for blacks generally in the South also improved. But if this gain is attributable to desegregation, the fact that it occurred for young students but not for the older ones reconciles the positive findings of the Southern desegregation evaluations with the NLS results in the South.

There is some evidence that desegregation increases black achievement in the long run as well as in the short run-at least in the South and in the early grades. The important questions are how desegregation raises achievement, to what extent it does, and what kinds of desegregation plans are most effective. These questions can best be considered together, since knowing that a certain type of plan is effective can provide clues to why desegregation works.

\section{B. Grade Level at Which Desegregation First Occurs}

Although most of the conclusions drawn from our review of the desegregation research are debatable, on one aspect the results are clear and unmistakable: the earlier the grade at which desegregation occurs, the more positive the impact on achievement. Of the studies we have reviewed, fourteen showed a more positive impact on the achievement scores of students desegregated in earlier grades than on those desegregated in the later grades. ${ }^{66}$ Only three found the opposite effect. Beker's study in Syracuse ${ }^{67}$ used a tiny sample-his total control group contained only twenty-three sta-

63. S. Johnson, Update on Education: A Digest of the National Assessment of Educational Progress (Education Commission of the States report, 1975) (ERIC Document No. 013381 ).

64. Id.

65. Until the Supreme Court's decision in Green v. New Kent County School Bd, 391 U.S. 430 (1968), followed by Alexander v. Holmes County Bd. of Educ., 396 U.S. 19 (1969) and Carter v. West Feliciana Parish School Bd., 396 U.S. 290 (1970), little more than token desegregation had occurred in the South. See Read, Judicial Evolution of the Law of School Integration Since Brown v, Board of Education, 39 Law \& Contemp. Prob., Winter 1975, at 7, 28-32.

66. The fourteen studies are: Louis Anderson, supra note 59; D. Catherine Baltzell, supra note 2; Clark County School District, supra note 40; Arthur Dambacher, supra note 40; James Fortenberry, supra note 53; Justin \& Thabit, supra note 2; Kurtz, supra note 2; Mahan \& Mahan, supra note 21; Maynor \& Katzenmeyer, supra note 39; B. Perry \& N. Kopperman, supra note 36; Schellenberg \& Halteman, supra note 25; Wolman, Learning Effects of Integration in New Rochelle, 2 INTEGRATED EdUC. 30 (1964); and Zdep, supra note 23.

67. Beker, A Study of Integration in Racially Imbalanced Urban Public Schools-A Demonstration and Evaluation (mimeographed final report, Syracuse University Youth Development Center, Syracuse, N.Y., 1967) (ERIC Document No. 012710 ). 
dents, which could hardly be sorted by grade and produce meaningful results. Evans's study of the first year of desegregation in Fort Worth also found a greater achievement gain in the higher rather than the lower grades, ${ }^{68}$ but his own follow-up study a year later reversed this conclusion. ${ }^{6}{ }^{\circ}$ The Dade County study also found larger achievement gains in the upper grades than in the lower grades, but this seems to be explained not by the high performance of upper-grade students assigned to white schools, but by a rather dramatic drop in the performance of the upper-grade students remaining in the segregated schools. ${ }^{70}$ The achievement of these segregated black students decreased by about a third of a year in comparison with the preceding year's class even though black achievement in other grades went up. The fourteen studies indicating greater achievement gains in the earlier grades are methodologially stronger than these three studies. ${ }^{71}$ Even some studies whose overall effects were zero show positive results in the early grades. ${ }^{72}$ St. John and Weinberg report three other studies in which stronger results occurred in the lower grades. ${ }^{73}$ Both reviewers have concluded that desegregating the early grades is preferable to desegregating older students. ${ }^{74}$

As a further test of the hypothesis, we related the impact of desegregation on achievement reported in the different studies to the grades that were tested. The results of this analysis support the conclusion that desegregation in the early grades is more successful in terms of achievement gains than is desegregation in later grades. Of twelve studies of desegregation undertaken at the junior high school and high school level, ${ }^{75}$ five showed negative ef-

68. Charles Evans, Short-term Desegregation Effects, supra note 15.

69. Charles Evans, Integration Evaluation, supra note 15.

70. Dade County Evaluation, supra note 55. The achievement levels of the control group declined by about a third of a year more than the preceding year's class, even though black achievement in other grades went up.

71. In particular, see Mahan \& Mahan, supra note 21; Zdep, supra note 23; and Schellenberg \& Halteman, supra note 25.

72. Examples are: Arthur Dambacher, supra note 40; James Fortenberry, supra note 53; Schellenberg \& Halteman, supra note 25; and Wolman, supra note 66.

73. Rochester City School District, A Three-Year Longitudinal Study to Assess a Fifteen-Point Plan to Reduce Racial Isolation and Provide Quality Integrated Education for Elementary Level Pupils (Rochester City School District report, Rochester, N.Y., September 1970) (ERIC Document No. 048 428); Shaker Heights School Board, An Interim Evaluation of the Shaker Schools Plan (mimeographed, Shaker Heights School Board, Shaker Heights, Ohio, February 1972); and Ivan Samuels, Desegregated Education and Differences in Academic Achievement (1958) (unpublished Ph.D. dissertation, Indiana University).

74. N. St. John, supra note 2, at 77-78; M. WEINBERG, supra note 17.

75. Dade County Evaluation, supra note 55; Felice, supra note 48; Maynor \& Katzenmeyer, supra note 39; R. Mayer, C. King, A. Borders-Patterson, \& J. McCullough, supra note 2; Frank Williams, supra note 59; Armor, supra note 15; B. Perry \& N. Kopperman, supra note 36; Herbert Walberg, supra note 15; Lemoyne Savage, Academic Achievement of Black Students Transferring from a Segregated Junior High School to an Integrated High School (July 1971) (unpublished Master's thesis, Virginia State College); Robert Klein, A Comparative Study of the Academic Achievement of Negro Tenth Grade High School Students Attending Segregated and Recently 
fects, ${ }^{76}$ while none of ten studies of desegregation undertaken in the first and second grades showed negative results. ${ }^{77}$ Data showing the relationship between achievement outcomes and grade level at which desegregation occurred are given in Table 4 for the sample of forty-one studies we reviewed, as well as for twenty-one additional studies for which Weinberg and St. John provided data by grade level. All three sets of studies support the hypothesis.

The critical point, as indicated by the data presented in Table 4 , is at the second or third grade, since only twelve of the twenty-four studies of desegregation that occurred in grades three or four showed positive achievement results. ${ }^{78}$ These grades are at the center of an age range that Inbar has

Integrated Schools in a Metropolitan Area of the South (1967) (unpublished Ph.D. dissertation, University of South Carolina); James Bryant, Some Effects of Racial Integration of High School Students on Standardized Achievement Test Scores, Teacher Grades and Drop-Out Rates in Angleton, Texas (1968) (unpublished Ed.D. dissertation, University of Houston); and James McCullough, Academic Achievement Under School Desegregation in a Southern City (mimeographed report, Department of City and Regional Planning, University of North Carolina at Chapel Hill, January 1972).

76. Dade County Evaluation, supra note 55; Felice, supra note 48; B. Perry \& N. Kopperman, supra note 36; Herbert Walberg, supra note 15; and James Bryant, supra note 75.

77. Louis Anderson, supra note 59; Frary \& Goolsby, supra note 58; Beker, supra note 67; Clark County School District, supra note 40; Frank Dressler, Study of Achievement in Reading of Pupils Transferred from Schools 15 and 37 to Peripheral Schools to Eliminate Overcrowding, to Abandon an Obsolete School, and to Achieve a More Desirable Racial Balance in City Schools (March 1967) (mimeographed report, Buffalo Public Schools Division of Curriculum Evaluation and Development, Buffalo, New York); H. Gerard \& N. Miller, supra note 40; Zdep, supra note 23; Barbara Heller, Project Concern: Westport, Connecticut (June 1972) (Center for Urban Education report, N.Y., N.Y.); William Rock, A Report on a Cooperative Program Between a City School District and a Suburban School District (June 28, 1968) (Rochester, N.Y.); and Joseph Samuels, A Comparison of Projects Representative of Compensatory, Busing, and Non-Compensatory Programs for Inner-City Students (1971) (unpublished Ph.D. dissertation, University of Connecticut).

78. The twelve showing positive results are: D. Catherine Baltzell, supra note 2; Charles Evans, Short-term Desegregation, and Integration Evaluation, supra note 15; R. MAYER, C. KING, A. Borders-Patterson, \& J. MCCullough, supra note 2; Denmark, supra note 38; Mahan \& Mahan, supra note 21; Syracuse City School District, Washington Irving and Host Pupils, supra note 15; Jayjia Hsia, supra note 15; Irene Slone, The Effects of One School Pairing on Pupil Achievement, Anxieties, and Attitudes (1968) (unpublished Ph.D. dissertation, New York University); Bruce Wood, The Effects of Bussing Versus Non-Bussing on the Intellectual Functioning of Inner City, Disadvantaged Elementary School Children (1969) (unpublished Ed.D. dissertation, University of Massachusetts); Ann Danahy, A Study of the Effects of Bussing on the Achievement, Attendance, Attitudes, and Social Choices of Negro Inner-City Children (1971) (unpublished Ed.D. dissertation, University of Minnesota); Harold Jonsson, Report of Evaluation of ESEA Title I Compensatory Activities for 1966-67 (1967) (mimeographed report, Berkeley Unified School District, Berkeley, California); and Ronald Clinton, A Study of the Improvement in Achievement of Basic Skills of Children Bused from Urban to Suburban School Environments (1969) (unpublished Master's thesis, Southern Connecticut State College).

The other twelve are: Justin \& Thabit, supra note 2; Patricia Carrigan, supra note 15; Arthur Dambacher, supra note 40; Arley Bondarin, The Racial Balance Plan of White Plains, New York (Report to the Center for Urban Education, N.Y., N.Y., 1970) (ERIC Document No. 012 710); Syracuse City School District, Croton and Edward Smith Elementary School Pupils, supra note 15; Schellenberg \& Halteman, supra note 25; Harry Singer, supra note 38; Wolman, supra note 66; F. 
TABLE 4

Grade First Desegregated Related to Achievement Outcomes

Studies of Southern Desegregation Reviewed by the Authors

Average (Mean) Grade First Desegregated

$\begin{array}{lcccccc} & 1-2 & 3-4 & 5-6 & 7-9 & 10-12 & \text { Total } \\ \text { Positive } & 2 & 3 & 2 & 2 & 1 & 10 \\ \text { Zero } & 0 & 0 & 1 & 0 & 0 & 1 \\ \text { Negative } & 0 & \frac{1}{4} & \frac{1}{4} & \frac{1}{3} & \frac{1}{2} & \frac{4}{15}(\gamma=.40) \\ \text { Total } & 2 & 4 & 50 \% & 67 \% & 50 \% & \end{array}$

Studies of Northern Desegregation Reviewed by the Authors

Average (Mean) Grade First Desegregated

$\begin{array}{lcccccc}\text { Positive } & 3 & 3 & 3 & 0 & 0 & 9 \\ \text { Zero } & 2 & 7 & 1 & 1 & 0 & 11 \\ \text { Negative } & 0 & \frac{3}{13} & \frac{1}{5} & \frac{2}{3} & \frac{0}{-} & \frac{6}{26}(\gamma=.36) \\ \text { Total } & 5 & 13 & & \end{array}$

Additional Studies Reviewed by Weinberg and/or St. John

Average (Mean) Grade First Desegregated

Positive

1-2 $\quad 3-4 \quad 5-6 \quad 7-9 \quad 10-12$ TotaL

Zero

3

Negative

Total

Percent Positive

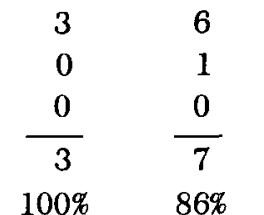

5

1

$0 \quad 15$

$\begin{array}{llll}5 & 0 & 2 & 8\end{array}$

Note: Only 25 of 32 studies reviewed by Weinberg and/or St. John appear in this table; the reviewer did not indicate the grade level at which desegregation occurred in the other 7 studies.

called the "vulnerable age."79 His study of persons migrating to Israel indicated that those who migrated between the ages of six and eleven were less likely later to attend college than those who came at either younger or older ages. ${ }^{80}$ This result was replicated by the same researcher using data on migra-

Aberdeen, supra note 15; Kurtz, supra note 2; Carolyn Thompson \& Frances Dyke, supra note 39; and George Rentsch, Open-Enrollment: An Appraisal (1967) (unpublished Ed.D. dissertation, State University of New York at Buffalo).

79. M. Inbar, The Vulnerable Age Phenomenon (1976).

80. M. Inbar \& C. Adler, Ethnic Integration in Israel: A Comparative Case Study of Moroccan Brothers Who Settled in France and in Israel 57 (1977). 
tion to Canada and regional migration within the United States. ${ }^{81}$ A similar pattern was found for blacks who migrated from the South to the North at this age. ${ }^{82}$ As early as 1953 , the theory was propounded that the elementary school years are an important period for establishing social relationships, so that social relationships should not be disrupted during this time. ${ }^{83}$ If this theory is correct, the social migration that occurs as a result of desegregation may have effects analogous to geographic migration.

It has been frequently urged that desegregation begin in the early grades. It is gratifying to see empirical evidence support the conventional wisdom so clearly-although if the Inbar finding is pertinent, even third grade may not be early enough.

\section{Curriculum Factors}

St. John argues that achievement gains as a result of desegregation are more likely to occur in mathematics than in reading. ${ }^{84}$ Of the forty-one studies we reviewed, ten show this to be the case ${ }^{85}$ Only three studies find stronger effects in reading than in mathematics. However, these three studies cannot be dismissed so easily, since they represent some of the methodologically best desegregation studies undertaken. ${ }^{86}$ The general rule seems to be that achievement gains are specifically related to curriculum. Where there is a marked difference in part of the curriculum of the sending and of the receiving schools, achievement changes-sometimes dramatic oneswill occur in that subject. It may be true that mathematics is usually easier to learn in most desegregated schools, but this may be because of curriculum differences and not a necessary consequence of racial interaction. ${ }^{87}$ One of the best examples of this is seen in the experiment undertaken by Zdep. ${ }^{88}$ The first-grade students randomly assigned to white suburban schools raised their achievement scores in mathematics three grade levels more than

81. M. INBAR, supra note 79 , at 6-8, 15.

82. R. Crain \& C. Weisman, Discrimination, Personality, and achievement 12 (1972).

83. H. Suli.ivan, The Interpersonal. Theory of Psychiatry 241-42 (1953); M. Inbar, supra note 79 , at 45 .

84. N. ST. JoHn, supra note 2, at 119.

85. Clark School District, supra note 40; Dade County Evaluation, supra note 55; Charles Evans, Short-term Desegregation, and Integration Evaluation, supra note 15; Felice, supra note 48; James Fortenberry, supra note 53; R. Mayer, C. King, A. Borders-Patterson, \& J. McCullough, supra note 2; Prichard, supra note 40; B. Perry \& N. Kopperman, supra note 36; Sacramento City Unified School District, Focus on Reading and Mathematics 1970-71: An Evaluation Report on a Program of Compensatory Education, ESEA Title I (July 1971) (Sacramento City Unified School District report, Sacramento, California); and Frank Williams, supra note 59.

86. R. Mayer, C. King, A. Borders-Patterson, \& J. McCullough, supra note 2; Mahan \& Mahan, supra note 21 ; Herbert Walberg, supra note 15.

87. Zdep, supra note 23 , at 181 .

88. Zdep, supra note 23. 
their segregated counterparts. ${ }^{89}$ At the same time the second graders in the desegregation experiment lost nearly half a grade level compared to their segregated counterparts. ${ }^{90}$ Zdep noted, however, that the suburban schools used a high quality modern math curriculum for which the transferring second graders had an inadequate background. The most dramatic example of what is probably a curriculum effect appears in Williams's evaluation of a desegregation program in a Florida county. ${ }^{91}$ The segregated secondary school was a six-year consolidated school with only 100 students per grade and only thirty teachers in the school. Williams noted that the curriculum was "not comprehensive." Half of the black students transferred at the end of the ninth grade to the white high school, which was much larger and had what Williams called a "fully comprehensive" high school program. The pretest administered in the ninth grade showed the transferring and control students to have the same verbal and quantitative IQ scores and achievement levels. The posttest, administered in the twelfth grade, showed the verbal IQ scores to be the same for both groups, but indicated that the quantitative IQ scores of the desegregated group had gone up a little over one and one-half grade levels. ${ }^{92}$ In achievement, their English-language skills had increased nearly three grade levels and their performance in social studies, math, and science had increased by a little less than one and one-half grade levels or more. ${ }^{93}$ Thus the desegregated students had all gained an average of two to three additional grades in achievement in three years. In other words, their rate of growth was more than double that of the segregated students, with no change in verbal IQ. The only plausible explanation for such extreme gains is that the white "comprehensive" high school had a markedly better curriculum.

Another study showing rather dramatic results that seem to be unexplainable except as a curriculum effect is Fortenberry's study of Oklahoma City. ${ }^{\mathbf{9 4}}$ His is one of the Southern studies that shows no positive overall effect of desegregation. The study does, however, show marked differences in individual subject matter areas. His control and treatment groups were matched on the basis of a sixth-grade achievement test. By the ninth grade, the desegregated students had declined seven-tenths of a grade in reading ability compared to the students in the control group. This is a disturbing result, but

89. Id. at 181 .

90. Id. Thus, the first graders attained a full standard deviation more than did their segregated control group while the desegregated second graders fell .15 standard deviations below the control group.

91. Frank Williams, supra note 59.

92. This amounts to 0.6 standard deviations.

93. This amounts to 0.9 standard deviations in English-langauage skills and 0.4 standard deviations in the other subjects.

94. James Fortenberry, supra note $\mathbf{5 3}$. 
it becomes especially intriguing in view of the fact that these same desegregated students went up 1.2 grade levels in language arts. Obviously, these tests are not measuring a single verbal skill; the black school must have been doing a better job teaching reading, but not the mechanics of writing.

In general, where there are radically different curricula, desegregation can have sharply different effects in specific subject matter areas. In most studies of elementary school desegregation, this will generally appear as greater achievement gains in mathematics for desegregated students. In high school, it may appear in any of a variety of subject matter areas. The remarkable results of the desegregation program in Brevard County, Florida, as found by Williams, ${ }^{95}$ can only be reconciled with the absence of any significant achievement differences between most segregated and desegregated Southern high schools as a result of desegregation, as indicated by the NLS analysis, by arguing that most of the woefully inadequate small segregated high schools of the South, located mostly in rural areas, had been closed by 1972 . The Southern black students in segregated schools surveyed by the NLS cannot have been attending schools like the one Williams studied.

\section{Voluntary and Mandatory Plans}

Desegregation plans were analyzed for this article according to whether the black students were mandatorily reassigned for desegregation or were volunteers. The results of this analysis are shown in Table 5. The twenty-six Northern studies that we reviewed show a definite pattern-achievement gains are more likely to occur when reassignment is mandatory. Only two positive results among the eleven studies of Northern voluntary plans were found, ${ }^{96}$ while of fifteen studies of Northern mandatory plans, seven showed positive results. ${ }^{97}$ The St. John and Weinberg studies that we have not yet reviewed show a similar pattern: voluntary plans are evaluated positively in nine of twelve studies, but mandatory plans show positive results seven times out of eight. ${ }^{98}$

95. See discussion at text accompanying notes 91-93, supra.

96. Zdep, supra note 23; J. TEELE, supra note 40.

97. The positive results are from the studies by: Beers \& Reardon, supra note 38; Clark County School District, supra note 40; Frank Dressler, supra note 77; Denmark, supra note 38; Mahan \& Mahan, supra note 21; Syracuse City School District, Washington Irving and Host Pupils, supra note 15; Sacramento City Unified School District, supra note 85; Kurtz, supra note 2; and F. Aberdeen, supra note 15, present negative findings. Zero findings are by Arley Bondarin, supra note 78; Patricia Carrigan, supra note 15; Arthur Dambacher, supra note 40; H. GERARD \& N. Miller, supra note 40; Schellenberg \& Halteman, supra note 25; and Harry Singer, supra note 38.

98. The nine studies of voluntary plans that obtained positive results are: David Archibald, Report on Change in Academic Achievement for a Sample of Elementary School Children: Progress Report on METCO (1967) (mimeographed report, Roxbury, Massachusetts); Ann Danahy, supra note 78; Mary Laird \& Grace Weeks, The Effect of Bussing on Achievement in Reading and Arithmetic in Three Philadelphia Schools (1966) (mimeographed report, School District of Philadelphia Division of Research, Philadelphia, Pennsylvania); William Rock, supra note 77; 
TABLE 5

Voluntary and Mandatory Plans in Northern School Districts
Related to Achievement Outcomes

Review Sample

$\begin{array}{lccc} & \text { Voluntary } & \text { Mandatory } & \text { Total } \\ \text { Positive } & 2 & 7 & 9 \\ \text { Zero } & 5 & 6 & 11 \\ \text { Negative } & 4 & \frac{2}{15} & \frac{6}{26} \\ \text { Total } & 11 & 47 \% & 35 \% \\ \text { Percent Positive } & 18 \% & & \gamma=.54\end{array}$

St. John/Weinberg Sample

$\begin{array}{lccc} & \text { Voluntary } & \text { Mandatory } & \text { Total } \\ \text { Positive } & 9 & 7 & 16 \\ \text { Zero } & 2 & 1 & 3 \\ \text { Negative } & 1 & \frac{0}{8} & \frac{1}{20} \\ \text { Total } & 12 & 87 \% & 80 \% \\ \text { Percent Positive } & 75 \% & & \gamma=.42\end{array}$

Review Sample Using Only Longitudinal Designs With Black Control Group

\section{Positive}

Zero

Negative

Total

Percent Positive
Voluntary

1

3

$\frac{2}{6}$

$17 \%$

\begin{tabular}{c} 
Mandato \\
4 \\
2 \\
0 \\
\hline 6
\end{tabular}

$67 \%$
Total

5

5

$\frac{2}{12}$

$42 \%$

$$
\gamma=.85
$$

Ronald Clinton, supra note 78; Barbara Heller, supra note 77; Joseph Samuels, supra note 77; Bruce Wood, supra note 78; and Wayne Scott, A Study of Bused and Non-Bused Children (June 1970) (Grand Rapids Public Schools report. Grand Rapids, Michigan). Among the studies of voluntary plans, the two zero-findings are by Bernice Brooks, A Study of Ninety-five Children Traveling by Bus to a K-5 School as Part of the Open Enrollment Program in a Large Urban School System (1969) (unpublished Ed.D. dissertation, Columbia University). A study of a voluntary plan that obtained negative results is Shaker Heights School Board, supra note 73. Of the studies of mandatory plans, the following show positive results: Harold Jonsson, supra note 78; Ronald Banks \& Mary Di Pasquale, A Study of the Educational Effectiveness of Integration (January 1969) (Buffalo Public Schools report, Buffalo, N.Y.); Jayjia Hsia, supra note 15; Irene Slone, supra note 78; Orrin Bowman, Scholastic Development of Disadvantaged Negro Pupils: A Study of Pupils in Selected Segregated and Desegregated Elementary Classrooms (1973) (unpublished Ph.D. dissertation, State University of New York at Buffalo); Ivan Samuels, supra note 73; San Francisco Unified School District, Evaluation of San Francisco Unified School District 
A methodological analysis of the exceptions was undertaken. Of the eleven voluntary plans, the two voluntary plans that produced positive results were those analyzed by $\mathrm{Zdep}^{99}$ and Teele. ${ }^{100}$ There are peculiar aspects of each study that might explain the aberrant results, although the peculiarities are not methodological. The Zdep study used random assignment. Although the Teele study is methodologically weak, because the Boston School Committee refused to allow the researcher access to a control group, Teele did a brilliant job of, to use his phrase, "patching up" the study. ${ }^{101}$ Both studies have some unusual aspects, however. The Zdep study involved a very strong quality of schooling effect, since the black students who remained in segregated schools were on half-day sessions due to overcrowding. This might explain a portion of the very large increase in achievement found for the desegregated students, who gained nearly three grade levels in the first and second grade overall. ${ }^{102}$

In addition, both experiments had a somewhat unusual method for recruiting volunteers. The voluntary-mandatory distinction in these studies is a continuum. Programs vary from highly voluntary plans, where only a small number of students select the plan (such as in the ABC Program of sending black students to prep school), ${ }^{103}$ all the way to a virtually mandatory plan such as that analyzed by Mahan and Mahan, in which 96 percent of the parents agreed to "volunteer." ${ }^{04}$ Zdep's design is almost identical to the Mahans', except that permission slips were requested before reassignment rather than after. ${ }^{105}$ Zdep does not give the exact number of parents who agreed to reassignment, but it is at least 50 percent. ${ }^{106}$ If a very large number of parents agreed to reassignment, then for all practical purposes the plan is identical to a mandatory plan. The Teele study is also different from most voluntary plans in that the volunteers were recruited not by the school district but by a private black parents' organization, Operation Exodus. ${ }^{107}$ An open en-

Desegregation Data from Integration 1971-1972 (1972) (San Francisco Unified School District report, San Francisco, California). A zero finding for a mandatory plan is reported in Marian Graves \& Frederick Bedell, A Three-Year Evaluation of the White Plains Racial Balance Plan (October 16, 1976) (mimeographed report of Board of Education, White Plains, N.Y.).

99. Zdep, supra note 23.

100. J. TEELE, supra note 40.

101. See J. TeEle, supra note 40, at 57-67. The account includes a description of the confrontation between the conservative school board and the black researcher who evaluated a black-run school program.

102. Zdep, supra note 23, at 181. The overall gain was 0.9 of a standard deviation. which took into account the .15 standard deviation loss in mathematics of the desegregated second graders compared to their segregated counterparts. See note 90 supra and accompanying text.

103. B. Perry \& N. Kopperman, supra note 36.

104. Mahan \& Mahan supra note 21, at 4.

105. Zdep, supra note 23 , at 175 .

106. Id.

107. J. TeELE, supra note 40, at 6-15. 
rollment plan in the North run by public school authorities appeals to a certain type of parent. Operation Exodus, which had an ideological community organization behind it, may have reached a very different set of parents.

Among the nine voluntary studies that did not find positive effects, there are several of good quality. The Fox study of open enrollment in New York City, which has a large sample size, found that students who volunteered for reassignment did not do as well as those who stayed behind in segregated schools. ${ }^{108}$ Two voluntary programs in Syracuse, ${ }^{109}$ the two evaluations of METCO, ${ }^{110}$ Wolman's evaluation in New Rochelle, ${ }^{111}$ and the Thompson and Dyke evaluation in Rochester ${ }^{12}$ also found no achievement gains resulting from desegregation. Two other studies are less useful since they dealt with private school populations: Perry's study of $\mathrm{ABC},{ }^{113}$ which is clearly not comparable to any public school program, and Gardner's analysis of open enrollment in the Chicago Catholic School System. ${ }^{114}$ The most that can be said here is that there seem to be some conditions under which voluntary programs are not successful.

A methodological analysis of the Northern mandatory studies indicates that the studies that obtained positive results are methodologically superior to those that did not. Of the fifteen Northern mandatory studies, eight do not show positive results, but seven of those eight have characteristics that weaken their conclusions. Aberdeen's study of desegregation in Ann Arbor, Michigan shows negative results, but he used national norms as the standard, and in the middle of the evaluation the school district changed the test it was using. ${ }^{115}$ Carrigan's study of Ann Arbor used black students attending an integrated school as the control group. ${ }^{116}$

The problems inherent in cohort analysis ${ }^{117}$ also plague the evaluations of the Riverside, California desegregation. ${ }^{118}$ Gerard and Miller attempted to use

108. David Fox, Colleen Stuart, and Vera Pitts, Services to Children in Open Enrollment Receiving Schools: Evaluation of ESEA Title I Projects in New York City, $1967-68$ (mimeographed report, New York Center for Urban Education, N.Y., N.Y., December 1968) (ERIC Document No. 034004 ).

109. Syracuse City School District, Croton and Edward Smith Elementary School Pupils, supra note 15, at 327-28; Syracuse City School District. Washington Irving and Host Pupils, supra note 15, at $323-326$

110. Herbert Walberg, supra note 15; Armor, supra note 15.

111. Wolman, supra note 66 , at 30 .

112. Carolyn Thompson \& Frances Dyke, supra note 39.

113. B. Perry \& N. Kopperman, supra note 36.

114. Burleigh Gardner, Benjamin Wright, and Sister Rita Dee, The Effect of Busing Black Ghetto Children into White Suburban Schools (report prepared for Chicago Catholic School Board, July 1970) (ERIC Document No. 048 389).

115. F. Aberdeen, supra note 15.

116. Patricia Carrigan, supra note 15. In analyzing Carrigan's study we used her cohort analysis. However, there are also weaknesses in cohort analyses. See discussion at pp. 27-28, supra.

117. See discussion at pp. 27-28, supra.

118. Harry Singer, supra note 38. H. Gerard \& N. Miller, supra note 40. 
a segregated control group, since one of the elementary schools in the district was desegregated in two stages, with half the students remaining behind for the first year. Thus, a comparison of the two halves of the student body, where, according to Gerard and Miller, there was no reason to believe that the two groups differed, shows the impact of an additional year of desegregation on one group but not on the other. However, the elementary school was entirely Mexican American, and consequently the evaluation is not comparable to studies of black-white desegregation. Fortunately, Gerard and Miller tabulated the data for blacks and Mexican Americans separately, which made it possible for us to construct a cohort evaluation for blacks. The cohort evaluation indicates no gain in achievement, but there is no information as to the sort of trends in achievement test administration that occurred independently of desegregation, what trends occurred in the composition of the district, or whether the various tests used at various times are exactly comparable. The Kurtz reanalysis of Evanston data, ${ }^{119}$ using a cohort design, also failed to produce positive results, but since he found that white as well as black scores were declining, the outcome is suspect. A cohort evaluation of Berkeley school desegregation is ambiguous, since although there was no change in achievement overall, the effects were positive in the lower grades. ${ }^{120}$ Both St. John and Weinberg reviewed other studies of Berkeley that showed positive outcomes. ${ }^{121}$ An evaluation in White Plains, which showed no significant effects, was based on a very small sample (treatment and control groups together amounted to sixty-nine students). ${ }^{122}$

In sum, it seems reasonable to discount heavily these seven studies of five cities. ${ }^{123}$ Thus, of the eight studies of Northern mandatory plans that do not show positive results, only the one by Schellenberg and Halteman seems to be a carefully designed study of good quality, with an adequate control sample. ${ }^{124}$

The seven studies that found positive results in Northern mandatory desegregation plans seem much stronger. ${ }^{125}$ Four of these use adequate con-

119. Kurtz, supra note 2.

120. Arthur Dambacher, supra note 40.

121. St. John cites positive findings by Harold Jonsson, supra note 78; Weinberg cites positive results in Frelow, Minority Administrators and Desegregation, 11 INTEG RATEd Educ. 27 (1973). See N. ST. JohN, supra note 2, at 158; M. WeINBERG, supra note 17 , at 117 .

122. Arley Bondarin, supra note 78 .

123. The cities are: Ann Arbor, Michigan, Riverside and Berkeley, California, White Plains, New York, and Evanston, Illinois.

124. Schellenberg \& Halteman, supra note 25. The problems in the Bondarin study of White Plains are not as serious as those in the other studies mentioned previously (see text accompanying notes 115-120, supra); still, the Bondarin study is weaker than the Schellenberg and Halteman study.

125. Syracuse City School District, Washington Irving and Host Pupils, supra note 15; Frank Dressler, supra note 77; Sacramento City Unified School District, supra note 85; Mahan \& Mahan, 
trol groups. The Syracuse study is based on a single school, ${ }^{126}$ but the Buffalo study, ${ }^{127}$ a study of the Sacramento school system, ${ }^{128}$ and a study of the Hartford Experiment ${ }^{129}$ used students from several schools. We systematically tested the hypothesis that the studies with positive findings are stronger methodologically than those with negative findings. The Northern studies that were longitudinal designs using a black control group were analyzed separately. These twelve studies, presented at the bottom of Table 5, show a stronger correlation between achievement outcomes and whether the plan is mandatory or voluntary. Four of the six mandatory studies show positive results, while only one of the six voluntary studies does.

On the whole, the evidence suggests that there is a significant correlation between mandatory assignment and positive achievement outcomes. ${ }^{130} \mathrm{We}$ are reluctant to recommend policies based on a finding so clearly counterintuitive, other than to suggest caution on the part of those recommending voluntary desegregation plans for blacks over mandatory plans and denouncing mandatory busing as an especially evil form of desegregation.

There are several possible explanations for the foregoing results. The obvious explanation is that the volunteering blacks are more talented than those that choose to remain in segregated schools, and that the desegregated blacks do not improve because they were doing well before desegregation. But this does not fit the data; volunteers generally do not have higher pretest scores. The opposite seems more plausible: elementary school students are volunteered for desegregation programs by their parents not because their children are doing well in segregated schools, but because they are doing poorly. Why reassign a student who is happy in school? Is it not more likely that in a program like METCO, parents will select the child who is doing badly in school, rather than the sibling who is doing well ${ }^{131}$ But doing well in school is partly, or perhaps largely, a matter of adaptation to bureaucratic structure and to authority. Transferring to a white school requires even more adaptation, and it may be that the least adaptive students were volunteered to make this transition. While this hypothesis does not make as much sense for secondary school students, none of the studies of voluntary plans involved secondary school students except the study of the prep school ABC Program. ${ }^{132}$ Presumably,

\footnotetext{
supra note 21; Denmark, supra note 38; Clark County School District, supra note 40; and Beers \& Reardon, supra note 38 .

126. Syracuse City School District, Washington Irving and Host Pupils, supra note 15.

127. Frank Dressler, supra note 77.

128. Sacramento City Unified School District, supra note 85.

129. Mahan \& Mahan, supra note 21.

130. The evidence is internally consistent and statistically significant at the .10 level. When the twenty-six studies reviewed by the authors are combined with the studies reviewed by St. John and Weinberg, the correlation is .25 .

131. See note I10, supra.

132. See B. Perry \& N. Kopperman, supra note 36.
} 
most secondary student volunteers are not motivated to change schools because they are doing badly where they are, but because they want to enhance their chances of going to college. This suggests the possibility of a positive self-selection bias in secondary school and a negative bias in elementary school. If this hypothesis is correct, then positive effects should occur for students transferring to predominantly white schools at the secondary level, or during kindergarten and first or second grade (before the average child has established an academic record on which a parent could base a decision). This hypothesis receives some support from the data, since the only studies of voluntary desegregation at kindergarten or first grade are Zdep's, ${ }^{133}$ which found positive effects, and Wolman's, ${ }^{134}$ which found the strongest effects at kindergarten, although the upper grades showed nonsignificant differences. St. John reports on two other studies of voluntary desegregation, one for kindergarten through second grade and one for second grade only, both of which show positive effects. ${ }^{135}$

The hypothesis that the least adaptive elementary school students will be volunteered does not seem plausible for the South, however. One would hardly expect a Southern black parent whose child was doing poorly in school to believe that he would be happier in a white school. It seems reasonable to argue that Southern pioneering parents were motivated mainly by ideological concerns. If this was the case, the lack of positive results from studies of voluntary desegregation in the South cannot be explained. The desegregated students are not doing as well as others who refused the opportunity to transfer, but they might have done worse than the nonvolunteers if they had remained in the segregated school. If so, there is a methodological error in the design, since the control group does not match the treatment group. The second possibility is that the students who refused to transfer would have benefited from desegregation while those who volunteered did not; this is an aptitude-treatment interaction effect.

Another hypothesis to explain the lack of positive outcomes from voluntary plans is that no one would have benefited from desegregation in such cases. We suspect that when the plan is voluntary, there is very little pressure on the receiving schools to adapt to the incoming students. The principal, teachers, and central administration may feel that if students are volunteering to transfer to their school, the school must be a good one and there is no reason to change. In contrast, mandatory desegregation often involves staff desegregation, in-service training of teachers, and curriculum changes. The

133. Zdep supra note 23 .

134. Wolman, supra note 66. at 30-31.

135. These studies are: Joseph Samuels, supra note 77: William Rock, supra note 77: N. ST. JoHN, supra note 2, at 154. 
new black teachers in the desegregated school may become spokesmen for the black students, and the community attention on the schools may make teachers and administrators feel that their student body has changed in some important ways, requiring the school to accommodate itself to this change. All of this activity may make mandatory desegregation work better than voluntary desegregation.

The final hypothesis is related to the theory of the impact of disrupting social relationships. ${ }^{136}$ If migration has unfortunate effects because it disrupts the newly forming social bonds of the elementary school child, then voluntary desegregation will disrupt this pattern more than a mandatory reassignment. In a mandatory plan, a black student either moves with many of his classmates to a classroom in a white school, or remains with many classmates while whites are brought into his school. In either case, the result is less disruptive than if he volunteers to move and leaves most of his classmates behind.

These hypotheses are tentative. We do not recommend that voluntary plans be terminated in Northern elementary schools on the basis of these data. But there are some recommendations that seem reasonable to make about voluntary desegregation plans instituted in the North:

1. Voluntary desegregation programs should begin in kindergarten or first grade.

2. Vigorous promotion efforts should be made to recruit as many volunteers as possible to minimize possible self-selection bias and create a critical mass of transferring students.

3. School faculty and staff should be permitted to recommend intensive remedial work for students who seem to have serious problems in school.

4. Receiving school staffs should be desegregated, and the receiving schools should be encouraged to use desegregation as an opportunity to achieve needed reforms in the school program.

IV

\section{Summary: What Can Be Said About Desegregation and Achievement?}

The best studies of the effects of school desegregation on the achievement of black students have in common a recognition of an important fact about desegregation-that desegregation is not a laboratory-controlled experiment that is identical in Jacksonville, Florida and in Berkeley, California. Every case is different, and identical results should not be expected. Thus one answer to the question, What is the effect of desegregation on achievement? is that sometimes it works and sometimes it doesn't. But this is true of any interven-

136. See notes 79-83, supra, and accompanying text. 
tion. Can anything more be said? The answer seems to be yes, but it is important to frame the question carefully. If the question is, Has desegregation resulted in improved achievement for blacks? the answer hardly needs study, since desegregation has resulted in the closing of many inadequate segregated schools in both the North and the South. If the question is, Will desegregation in the future improve the achievement of black students? the answer seems to be yes, with perhaps some reservations.

Pooling the data from the forty-one studies reviewed by the authors and the thirty-two studies reviewed by St. John and Weinberg, thirty-nine studies of desegregation plans involving mandatory assignment of black students have been identified in both the North and the South. Twenty-four of these evaluations report achievement gains, and five show losses-a four-to-one ratio favoring positive outcomes. The average gain in achievement (on the few studies where we have been able to code quantitative data) is around one-half of a grade-equivalent change in the first one or two years. The input-output studies show somewhat larger differences.

A policymaker will not be satisfied with this answer, however. He may ask, "Which is the most effective way to raise the achievement levels of black students-through desegregation or through improving the quality of education in segregated schools?" Here the answer is probably that both approaches are effective; not enough research has been done to determine which is more effective. If the policymaker then asks, "Are the gains in black achievement resulting from desegregation worth the social and political cost?" the question has no scientific answer, and becomes a matter of values.

We have stressed the differences between these various questions in order to suggest that the contradictory statements made by social scientists reflect not only disagreement about the data, but disagreement about the question being asked. The best examples of this confusion are the statements made about desegregation's impact on the achievement gap. Certainly differences between black and white achievement are interesting, but the idea that black achievement is only worth having if it erases the gap seems to be based on a confused idea of the policy issues. There is also confusion about the sorting out of the direct and indirect effects of desegregation. For example, are the $Z_{\text {dep }}{ }^{137}$ and Williams ${ }^{138}$ studies a fair test of desegregation's effects, since in one case the black school used as the control was hopelessly overcrowded and in the other case had an inadequate curriculum? The answer is certainly yes, since desegregation was the policy instrument that provided uncrowded schools and adequate curricula for these blacks. This does not mean that desegregation always means movement from a poor educational situation to a

137. Zdep, supra note 23.

138. Frank Williams, supra note 59. 
better one, which is why other studies do not show effects similar to these two. Both the Zdep and Williams studies recorded black achievement gains of from one and one-half to three grade levels in two to three years. ${ }^{139}$ More typical positive results are on the order of a little over half a grade level. ${ }^{140}$

Part of the confusion surrounding desegregation research arises because academics have frequently not viewed desegregation from a policymaking viewpoint. They have been too fascinated by what is intellectually the most interesting question: All else being equal, will the mixing of races alone result in higher black achievement? That question cannot be answered, because in the real world desegregation is never an "all else being equal" situation. Desegregation sometimes results in better curricula or facilities; it often results in blacks having better trained or more cognitively skilled teachers; it is frequently accompanied by a major effort to upgrade the quality of education; and it almost always results in socioeconomic desegregation. When desegregation is accompanied by all of these factors, it should not be surprising that there are immediate achievement gains half to two-thirds of the time. This suggests that desegregation is sufficient but not necessary to obtain these gains, since there are other ways to achieve curriculum reform or better teaching if the political will is present.

The presence of all these complicating factors makes it difficult to determine exactly why desegregation has beneficial achievement effects when it does, and why it sometimes fails to produce these effects. Various writers have argued that desegregation is most successful in raising achievement when it results in one or more of five favorable conditions:

1. Black students have transferred to schools that have better facilities and better teaching.

2. The expectations to which blacks are held are higher in their new schools.

3. The newly desegregated schools have undergone a flurry of inservice preparation for teachers and have adopted new curricula.

4. Black students are influenced by higher-status, college-bound white peers with better study habits and less rebellious attitudes toward school.

5. Black students develop a greater amount of self-confidence from discovering that they can cope, both socially and academically, in a white environment.

However, it is easy to imagine a desegregated situation where none of these five conditions occurs. Thanks to Title I of the Elementary and Secondary

139. The achievement gains found in the two studies are .5 to 1.0 standard deviations. Zdep, supra note 23, at 181; Frank Williams, supra note 59.

140. This amount of gain is approximately .2 standard deviations. 
Education Act $^{141}$ and the national concern about black achievement, many allblack schools have excellent facilities and staff. The white receiving schools may have teachers who are lazy or unconcerned, or whose training is obsolete. They may hold unfavorable attitudes toward blacks and express this in the low expectations they set for black students. The school may be unwilling to adapt to the new situation. Race relations may be so poor that peer effects across races cannot occur, and black students may develop a sense of futility.

Between these two extremes are more complex cases, when one or another of these favorable factors appears, while others do not. For example, what achievement effects can be expected in schools that are desegregated but predominantly black? If the white minority is bused into the school, the school administration may go to great lengths to strengthen the curriculum and modernize the facilities. On the other hand, if the white minority is a lowincome group living near a black neighborhood, the school may be perceived as a slum school and treated as one, so that few significant reforms may result. As we begin to tease out the possibilities, we can see that the pattern of interaction effects is very complex.

In future research, the authors of this interim report plan to search for these higher-order relationships to answer some of the following questions:

1. What is the optimal racial composition of a desegregated school?

a. Does this differ for different socioeconomic mixes?

b. Does the optimum change during the first few years of the plan?

2. What is the impact of desegregation over time? Are achievement effects cumulative, or is there a "honeymoon" followed by a crisis?

3. What is the impact on desegregation of white and black student socioeconomic status? Is there an optimal difference between the socioeconomic backgrounds of black and white students brought together by desegregation for producing achievement gains?

We suspect that if these questions can be answered we will be closer to knowing why desegregation raises black achievement in the short run (as it often appears to do) and in the long run (which apparently it almost always does). We should certainly know why it fails in the short run, which also happens. We do not believe that research will ever tell us whether desegregation is "good" or "bad," since this is more a matter of values than of data.

141. 20 U.S.C. $\$ 241$ a (1976). 


\section{APPENDIX I \\ List of Studies Reviewed by the Authors}

† Aberdeen, Frank D. "Adjustment to Desegregation: A Description of Some Differences Among Negro Elementary School Pupils." Ed.D. dissertation, University of Michigan, 1969. University Microfilms Order No. 70-04025.

$¥$ Anderson, Louis V. "The Effect of Desegregation on the Achievement and Personality Patterns of Negro Children." Ph.D. dissertation, George Peabody College for Teachers, 1966. University Microfilms Order No. 66-11237.

* Armor, David J. "The Evidence on Busing." The Public Interest 28 (1972), pp. 90-126.

Baltzell, D. Catherine. "Rapid Desegregation and Academic Achievement in a Large Urban School District." Paper presented at the annual meeting of the American Education Research Association, April 1974, in Chicago, Illinois. ERIC Document No. 090282.

Beers, Joan S., and Reardon, Francis J. "Racial Balancing in Harrisburg: Achievement and Attitudinal Changes." Integrated Education 12 (1974), pp. 35-38.

* Beker, Jerome. "A Study of Integration in Racially Imbalanced Urban Public Schools-A Demonstration and Evaluation." Final report to the Syracuse University Youth Development Center, Syracuse, New York, May 1967. Mimeographed.

Bondarin, Arley. "The Racial Balance Plan of White Plains, New York." Report to the Center for Urban Education, New York, New York, 1970. ERIC Document No. 012710 .

$\ddagger$ Carrigan, Patricia M. "School Desegregation via Compulsory Pupil Transfer: Early Effects on Elementary School Children." Ann Arbor, Michigan: Ann Arbor Public Schools, September 1969. ERIC Document No. 036597.

Clark County School District. "Desegregation Report." Las Vegas, Nevada: Clark County School District, July 1974. ERIC Document No. 106397.

Dade County Public Schools Department of Program Evaluation. "Evaluation of Desegregation 1970-1971." Miami, Florida: Dade County Public Schools, June 1972. ERIC Document No. 070792.

$\S$ Dambacher, Arthur D. "A Comparison of Achievement Test Scores Made by Berkeley Elementary Students Pre and Post Integration Eras, 1967-1970." Mimeographed. Berkeley, California: Berkeley Unified School District, 1971.

$\dagger$ Denmark, Florence L. "The Effect of Integration on Academic Achievement and Self-concept." Integrated Education 8 (1970), pp. 34-41.

* Dressler, Frank J. "Study of Achievement in Reading of Pupils Transferred from Schools 15 and 37 to Peripheral Schools to Eliminate Overcrowding, to Abandon an Obsolete School, and to Achieve a More Desirable Racial Balance in City Schools." Mimeographed. Buffalo, New York: Buffalo Public Schools, Division of Curriculum Evaluation and Development, March 1967.

If Evans, Charles L. "Short-term Desegregation Effects: The Academic Achievement of Bused Students, 1971-72." Fort Worth, Texas: Fort Worth Independent School District, 1973. ERIC Document No. 086759.

I Evans, Charles L. "Integration Evaluation: Desegregation Study II-Academic Effects on Bused Black and Receiving White Students, 1972-73." Fort Worth, Texas: Fort Worth Independent School District, 1973. ERIC Document No. 094087. 
Felice, Lawrence G. "The Effects of School Desegregation on Minority Group Student Achievement and Self-Concept: An Evaluation of Court-Ordered Busing in Waco, Texas." Waco, Texas: Research Development Foundation, 1974. ERIC Document No. 094096.

* Fortenberry, James H. "The Achievement of Negro Pupils in Mixed and Non-Mixed Schools." Ed.D. dissertation, University of Oklahoma, 1959. University Microfilms Order No. 59-05492.

* Fox, David J., Stuart, Colleen, and Pitts, Vera. "Services to Children in Open Enrollment Receiving Schools: Evaluation of ESEA Title I Projects in New York City, 1967-68." Mimeographed. New York, New York: New York Center for Urban Education, December 1968. ERIC Document No. 034004.

* Frary, Robert B., and Goolsby, Thomas M. "Achievement of Integrated and Segregated Negro and White First Graders in a Southern City." Integrated Education 8 (1970), pp. 48-52.

* Gardner, Burleigh B., Wright, Benjamin D., and Sister Rita Dee. "The Effect of Busing Black Ghetto Children into White Suburban Schools." Archdiocese of Chicago, Illinois: Chicago Catholic School Board, July 1970. ERIC Document No. 048389 .

† Gerard, Harold B., and Miller, Norman. School Desegregation: A Long-Term Study. New York: Plenum Press, 1975.

Justin, Neal E., and Thabit, Judy. "Black and White Achievement Before and After Integration," Intellect 102 (1974), pp. 458-59.

Kurtz, Harold. "An Independent Assessment of 'Integration in Evanston, 1967-1971: A Longitudinal Evaluation': A Report on the Educational Consequences of Desegregation in District 65 of Evanston, Illinois." U.S. Congress, House Committee on the Judiciary, Subcomm. No. 5, 92d Cong., 2d Sess., 1972, pp. 1436-43.

$\S$ Mahan, Thomas W., and Mahan, Aline M. "The Impact of Schools on Learning: Inner-City Children in Suburban Schools." Journal of School Psychology 9 (1971), pp. $1-11$.

\# Mayer, Robert R., King, C., Borders-Patterson, A., and McCullough, J. The Impact of School Desegregation in a Southern City. Boston: D.C. Heath, 1974.

Maynor, Waltz, and Katzenmeyer, W. G. "Academic Performance and School Integration: A Multi-Ethnic Analysis." Journal of Negro Education 43 (1974), pp. 30-38.

* Perry, George A., and Kopperman, N. "A Better Chance: Evaluation of Student Attitudes and Academic Performance, 1964-1972." Boston: A Better Chance, 1973. ERIC Document No. 075556.

$\ddagger$ Prichard, Paul N. "The Effects of Desegregation on Student Success in the Chapel Hill Schools." Integrated Education 7 (1969), pp. 33-38.

$\ddagger$ Sacramento City Unified School District. "Focus on Reading and Mathematics 1970-71: An Evaluation Report on a Program of Compensatory Education, ESEA Title I. Sacramento, California: Sacramento City Unified School District, July 1971.

Schellenberg, James, and Halteman, John. "Bussing and Academic Achievement: A Two-Year Follow Up." Urban Education 10 (1976), pp. 357-65.

Singer, Harry. "Effect of Integration on Achievement of Anglos, Blacks, and MexicanAmericans." Paper presented at the annual meeting of the American Education 
Research Association, March 3-6, 1970, in Minneapolis, Minnesota. ERIC Document No. 041975.

* Stallings, Frank H. "A Study of the Immediate Effects of Integration on Scholastic Achievement in the Louisville Public Schools." Journal of Negro Education 28 (1959), pp. 439-44.

† Stephenson, Robert, and Spieth, Phillip. "Evaluation of Desegregation 1970-1971." Miami, Florida: Dade County Public Schools Department of Program Evaluation, June 1972. ERIC Document No. 070792.

$\dagger$ Syracuse City School District. "Study of the Effect of Integration-Croton and Edward Smith Elementary School Pupils." In Hearing Held in Rochester, New York, September 16-17. U.S. Commission on Civil Rights, 1966, pp. 327-28.

† Syracuse City School District. "Study of the Effect of Integration-Washington Irving and Host Pupils." Hearing Held in Rochester, New York, September 16-17. U.S. Commission on Civil Rights, 1966, pp. 323-36.

$\dagger$ Teele, James E. Evaluating School Busing: A Case Study of Boston's Operation Exodus. New York: Praeger, 1973. ERIC Document No. 083334

$\dagger$ Thompson, Carolyn E., and Dyke, Frances L. First Interim Evaluation Report: UrbanSuburban Pupil Transfer Program 1971-1972. Rochester, New York: Rochester City School District, August 1972. ERIC Document No. 068609.

$\ddagger$ Walberg, Herbert J. An Evaluation of an Urban-Suburban School Busing Program: Student Achievement and Perception of Class Learning Environment. Paper presented at the annual meeting of the American Education Research Association, February 1971, in New York, New York. ERIC Document No. 047076.

¥Williams, Frank E. "An Analysis of Some Differences Between Negro High School Seniors from a Segregated High School and a Nonsegregated High School in Brevard County, Florida." Ed.D. dissertation, University of Florida, 1968. University Microfilms Order No. 69-17050.

¥ Wolman, T.G. "Learning Effects of Integration in New Rochelle." Integrated Education 2 (1964), pp. 30-31.

$\S$ Zdep, Stanley M. "Educating Disadvantaged Urban Children in Suburban Schools: An Evaluation." Journal of Applied Social Psychology 1 (1971), pp. 173-8.

\footnotetext{
* Referenced by St. John

+ Referenced by Weinberg

$\ddagger$ Referenced by St. John and Weinberg

$\S$ St. John and Weinberg cite different versions of the same study

If Evans's 1971-72 and 1972-73 studies were coded separately.

\# Mayer's ninth grade had no control group and consequently was coded separately.
} 


\author{
APPENDIX II \\ Studies Not Received by Press Time but Reviewed by St. John
}

Archibald, David K. "Report on Change in Academic Achievement for a Sample of Elementary School Children: Progress Report on METCO." Mimeographed. Roxbury, Massachusetts, 1967.

Clinton, Ronald R. "A Study of the Improvement in Achievement of Basic Skills of Children Bused from Urban to Suburban School Environments." Master's thesis, Southern Connecticut State College, 1969.

Danahy, Ann H. "A Study of the Effects of Bussing on the Achievement, Attendance, Attitudes, and Social Choices of Negro Inner-City Children." Ed.D. dissertation, University of Minnesota, 1971. University Microfilms Order No. 72-14285.

Heller, Barbara R. "Project Concern: Westport, Connecticut." New York: Center for Urban Education, June 1972.

Jonsson, Harold A. "Report of Evaluation of ESEA Title I Compensatory Activities for 1966-67." Mimeographed. Berkeley, California: Berkeley Unified School District, 1967.

Laird, Mary, and Weeks, Grace. "The Effect of Bussing on Achievement in Reading and Arithmetic in Three Philadelphia Schools." Mimeographed. Philadelphia, Pennsylvania: School District of Philadelphia, Division of Research, 1966.

McCullough, James S. "Academic Achievement Under School Desegregation in a Southern City." Mimeographed. Chapel Hill, North Carolina: Department of City and Regional Planning. University of North Carolina at Chapel Hill, January 1972.

Rentsch, George J. "Open-Enrollment: An Appraisal." Ed.D. dissertation, State University of New York at Buffalo, 1967. University Microfilms Order No. 67-11516.

Rock, William C. "A Report on a Cooperative Program Between a City School District and a Suburban School District." Rochester, New York, June 28, 1968.

Shaker Heights School Board. "An Interim Evaluation of the Shaker Schools Plan." Mimeographed. Shaker Heights, Ohio: Shaker Heights School Board, February 1972.

\title{
APPENDIX III
}

Studies Not Received by Press Time but Reviewed by Weingerg

Bowman, Orrin H. "Scholastic Development of Disadvantaged Negro Pupils: A Study of Pupils in Selected Segregated and Desegregated Elementary Classrooms." Ph.D. dissertation, State University of New York at Buffalo. 1973. University Microfilms Order No. 73-19176.

Brooks, Bernice D. "A Study of Ninety-five Children Traveling by Bus to a K-5 School as Part of the Open Enrollment Program in a Large Urban School System." Ed.D. dissertation. Columbia University, 1969. University Microfilms Order No. $71-08957$.

Clark, El Nadal. "Analysis of the Differences Between Pre- and Post-Test Scores (Change Scores) on Measures of Self-Concept, Academic Aptitude, and Reading Achievement Earned by Sixth Grade Students Attending Segregated and Desegregated Schools." Ed.D. dissertation. Duke University. 1971. University Microfilms Order No. 72-00307. 
Howell, William L. "The Correlates of Change in School Integration With the Academic Achievement of Eighth Grade Students." Ph.D. dissertation, University of South Carolina, 1972. University Microfilms Order No. 72-18153.

Moore, Louise M. "The Relationship of Selected Pupil and School Variables and the Reading Achievement of Third-Year Primary Pupils in a Desegregated School Setting." Ed.D. dissertation, University of Georgia, 1971. University Microfilms Order No. 72-11018.

Samuels, Ivan G. "Desegregated Education and Differences in Açademic Achievement." Ph.D. dissertation, Indiana University, 1958. University Microfilms Order No. 58-02934.

San Francisco Unified School District. "Evaluation of San Francisco Unified School District Desegregation Data from Integration 1971-1972." San Francisco, California: San Francisco Unified School District, 1972.

Savage, LeMoyne W. "Academic Achievement of Black Students Transferring from a Segregated Junior High School to an Integrated High School." Master's thesis, Virginia State College, 1971.

Scott, Wayne. A Study of Bused and Non-Bused Children. Grand Rapids, Michigan: Grand Rapids Public Schools, June 1970.

Starnes, Thomas A. "An Analysis of the Academic Achievement of Negro Students in the Predominantly White Schools of a Selected Florida County." Ed.D. dissertation, University of Southern Mississippi, 1968. University Microfilms Order No. 68-14712.

\section{APPENDIX IV}

Studies Not Received by Press Time but Reviewed by St. John and Weinberg

Banks, Ronald, and Di Pasquale, Mary E. "A Study of the Educational Effectiveness of Integration." Buffalo, New York: Buffalo Public Schools, January 1969.

Bryant, James C. "Some Effects of Racial Integration of High School Students on Standardized Achievement Test Scores, Teacher Grades and Drop-Out Rates in Angleton, Texas." Ed.D. dissertation, University of Houston, 1968. University Microfilms Order No. 69-00768.

Graves, Marian F., and Bedell, Frederick D. "A Three-Year Evaluation of the White Plains Racial Balance Plan." Mimeographed. White Plains, New York: Board of Education, October 1967.

Griffin, Jack L. "The Effects of Integration on Academic Aptitude, Classroom Achievement, Self-Concept, and Attitudes Toward the School Environment of a Selected Group of Negro Students in Tulsa, Oklahoma." Ed.D. dissertation. University of Tulsa, 1969. University Microfilms Order No. 69-17923.

Hsia, Jayjia. "Integration In Evanston, 1967-1971: A Longitudinal Evaluation." Evanston, Illinois: Educational Testing Service, August 1971. ERIC Document No. 054292.

Klein, Robert S. "A Comparative Study of the Academic Achievement of Negro Tenth Grade High School Students Attending Segregated and Recently Integrated Schools in a Metropolitan Area of the South." Ph.D. dissertation. University of South Carolina, 1967. University Microfilms Order No. 67-15565.

Marcum, Roger B. "An Exploration of the First-Year Effects of Racial Integration of the Elementary Schools in a Unit School District." Ed.D. dissertation. University of Illinois at Urbana-Champaign, 1968. University Microfilms Order No. 69-10784. 
Moorefield, Thomas E. "The Bussing of Minority Group Children in a Big City School System." Doctoral dissertation, University of Chicago, 1968.

Rochester City School District. "Final Report: A Three-Year Longitudinal Study to Assess a Fifteen-Point Plan to Reduce Racial Isolation and Provide Quality Integrated Education for Elementary Level Pupils." Rochester, New York: Rochester City Schools, September 1970. ERIC Document No. 048428.

Samuels, Joseph M. "A Comparison of Projects Representative of Compensatory, Busing, and Non-Compensatory Programs for Inner-City Students." Ph.D. dissertation, University of Connecticut, 1971. University Microfilms Order No. $71-14252$.

Slone, Irene W. "The Effects of One School Pairing on Pupil Achievement, Anxieties, and Attitudes." Ph.D. dissertation, New York University, 1968. University Microfilms Order No. 68-11808.

Wood, Bruce H. "The Effects of Bussing Versus Non-Bussing on the Intellectual Functioning of Inner City, Disadvantaged Elementary School Children." Ed.D. dissertation, University of Massachusetts, 1969. University Microfilms Order No. 69-05186. 